\title{
Fluoxetine Exposure during Adolescence Alters Responses to Aversive Stimuli in Adulthood
}

\author{
Sergio D. Iñiguez, ${ }^{1}$ Lyonna F. Alcantara, ${ }^{2}$ Brandon L. Warren, ${ }^{2}$ Lace M. Riggs, ${ }^{1}$ Eric M. Parise, ${ }^{2}$ Vincent Vialou, ${ }^{3}$ \\ Katherine N. Wright, ${ }^{2}$ Genesis Dayrit, ${ }^{1}$ Steven J. Nieto, ${ }^{1}$ Matthew B. Wilkinson, ${ }^{3}$ Mary K. Lobo, ${ }^{4}$ Rachael L. Neve, ${ }^{5}$ \\ Eric J. Nestler, ${ }^{3}$ and Carlos A. Bolaños-Guzmán ${ }^{2}$ \\ ${ }^{1}$ Department of Psychology, California State University, San Bernardino, California 92407, ${ }^{2}$ Department of Psychology and Program in Neuroscience, \\ Florida State University, Tallahassee, Florida 32306, ${ }^{3}$ Fishberg Department of Neuroscience, Mount Sinai School of Medicine, New York, New York 10029, \\ ${ }^{4}$ Department of Anatomy and Neurobiology, University of Maryland School of Medicine, Baltimore, Maryland 21201, and ${ }^{5}$ Massachusetts Institute of \\ Technology, Cambridge, Massachusetts 02139
}

The mechanisms underlying the enduring neurobiological consequences of antidepressant exposure during adolescence are poorly understood. Here, we assessed the long-term effects of exposure to fluoxetine (FLX), a selective serotonin reuptake inhibitor, during adolescence on behavioral reactivity to emotion-eliciting stimuli. We administered FLX ( $10 \mathrm{mg} / \mathrm{kg}$, bi-daily, for $15 \mathrm{~d})$ to male adolescent [postnatal day 35 (P35) to P49] C57BL/6 mice. Three weeks after treatment (P70), reactivity to aversive stimuli (i.e., social defeat stress, forced swimming, and elevated plus maze) was assessed. We also examined the effects of FLX on the expression of extracellular signalregulated kinase (ERK) 1/2-related signaling within the ventral tegmental area (VTA) of adolescent mice and Sprague Dawley rats. Adolescent FLX exposure suppressed depression-like behavior, as measured by the social interaction and forced swim tests, while enhancing anxiety-like responses in the elevated plus maze in adulthood. This complex behavioral profile was accompanied by decreases in ERK2 mRNA and protein phosphorylation within the VTA, while stress alone resulted in opposite neurobiological effects. Pharmacological (U0126) inhibition, as well as virus-mediated downregulation of ERK within the VTA mimicked the antidepressant-like profile observed after juvenile FLX treatment. Conversely, overexpression of ERK2 induced a depressive-like response, regardless of FLX pre-exposure. These findings demonstrate that exposure to FLX during adolescence modulates responsiveness to emotion-eliciting stimuli in adulthood, at least partially, via long-lasting adaptations in ERK-related signaling within the VTA. Our results further delineate the role ERK plays in regulating mood-related behaviors across the lifespan.

Key words: anxiety; depression; ERK; MAPK; SSRI; stress

\section{Introduction}

Major depressive disorder (MDD) affects up to $8 \%$ of the juvenile population (Kapornai and Vetró, 2008), resulting in negative functional consequences that extend into adulthood (Birmaher et al., 2007). Prozac [fluoxetine (FLX)], a selective serotonin reuptake inhibitor, is a therapeutic agent approved by the Food and Drug Administration to treat pediatric MDD (Hammerness et al., 2006). This has led to a significant increase in the prescription

Received Dec. 14, 2012; revised Nov. 30, 2013; accepted Dec. 6, 2013.

Author contributions: S.D.I. and C.A.B.-G. designed research; S.D.I., L.F.A., B.L.W., L.M.R., E.M.P., V.V., K.N.W., G.D., S.J.N., M.B.W., and M.K.L. performed research; R.L.N. and E.J.N. contributed unpublished reagents/analytic tools; S.D.I. and C.A.B.-G. analyzed data; S.D.I. and C.A.B.-G. wrote the paper.

This research was supported by National Institute on Drug Abuse Grants R24DA033877 (to S.D.I.) and R01DA026854 (to C.A.B.-G.), National Institute of Mental Health Grants P50MH096890 (to E.J.N.) and T32MH093311 (to B.L.W.), National Institute of Child Health and Human Development Grant HD052368 (to S.D.I.), a grant from the American Psychological Association (to S.D.I.), a McKnight Fellowship from the Florida Education Fund (to L.F.A.), and Associated Student Incorporated research grants (to L.M.R., G.D., and S.J.N.) from California State University, San Bernardino. We thank Norma N. Zamora for excellent technical assistance.

The authors declare no competing financial interests.

Correspondence should be addressed to Dr. Sergio D. Iñiguez, Department of Psychology, California State University, San Bernardino, CA 92407. E-mail: iniguez@csusb.edu.

DOI:10.1523/JNEUROSCI.5725-12.2014

Copyright $\odot 2014$ the authors $\quad 0270-6474 / 14 / 341007-15 \$ 15.00 / 0$ rate of FLX in this population (Zito et al., 2006), even though the majority of testing regarding its effectiveness and safety has been conducted in adults (Coyle et al., 2003; Olivier et al., 2011). This is remarkable given the pivotal role that the serotonin system plays in the regulation of brain development (Blakemore and Choudhury, 2006; Azmitia, 2007), that pharmacodynamic differences between developing and adult organisms are consistently reported (Iñiguez et al., 2008a; Correll et al., 2011; Neville et al., 2011), and that early-life pharmacological intervention often results in life-long neurobehavioral alterations (Bolaños et al., 2003b; Halladay et al., 2009; Oberlander et al., 2009).

The long-lasting functional consequences of FLX exposure during adolescence have recently begun to be elucidated. Juvenile FLX treatment enhances sensitivity to anxiety-eliciting environments (Homberg et al., 2011) while decreasing reactivity to acute inescapable stress conditions in adulthood (Karpova et al., 2009; Iñiguez et al., 2010a). The neurobiological mechanisms underlying these effects are unknown. Nevertheless, the antidepressant mechanisms of FLX have been linked to adaptations in postreceptor signaling since chronic, not acute, administration is required for its therapeutic effects (Berton and Nestler, 2006; Racagni and Popoli, 2008). For example, within the ventral teg- 
Table 1. Experimental groups

\begin{tabular}{|c|c|c|c|c|c|c|c|c|}
\hline Group & Subject & $N$ & Treatment & Age & Interval & Procedure I & Interval & Procedure II \\
\hline 1 & Mouse & 18 & VEH or FLX & P35-P49 & $21 \mathrm{~d}$ & Social defeat (10 d) & $24 \mathrm{~h}$ & Social interaction \\
\hline 2 & Mouse & 16 & VEH or FLX & P35-P49 & $21 d$ & Control housing (10 d) & $24 \mathrm{~h}$ & Social interaction \\
\hline 3 & Mouse & 19 & VEH or FLX & P35-P49 & $21 \mathrm{~d}$ & FST & & \\
\hline 4 & Mouse & 18 & VEH or FLX & P35-P49 & $21 \mathrm{~d}$ & Social defeat (10 d) & $24 \mathrm{~h}$ & FST \\
\hline 5 & Mouse & 20 & VEH or FLX & P35-P49 & $21 d$ & EPM & & \\
\hline 6 & Mouse & 19 & VEH or FLX & P35-P49 & $21 \mathrm{~d}$ & Social defeat (10 d) & $24 \mathrm{~h}$ & EPM \\
\hline 7 & Mouse & 16 & VEH or FLX & P35-P49 & $24 \mathrm{~h}$ & $q P C R$ & & \\
\hline 8 & Mouse & 17 & VEH or FLX & P35-P49 & $21 d$ & $q P C R$ & & \\
\hline 9 & Rat & 18 & VEH or FLX & P35-P49 & $24 \mathrm{~h}$ & $q P C R$ & & \\
\hline 10 & Rat & 15 & VEH or FLX & P35-P49 & $21 d$ & $q P C R$ & & \\
\hline 11 & Rat & 16 & VEH or FLX & P35-P49 & $21 d$ & Western blot & & \\
\hline 12 & Mouse & 14 & VEH & P35-P49 & $21 d$ & Social defeat (10 d) & $24 \mathrm{~h}$ & $q P C R$ \\
\hline 13 & Mouse & 26 & VEH & P35-P49 & $17 \mathrm{~d}$ & Cannulation & $7-8 d$ & FST (U0126 infusion) \\
\hline 14 & Mouse & 38 & VEH or FLX & P35-P49 & $17 \mathrm{~d}$ & HSV surgery & $3 d$ & Social defeat (submaximal) \\
\hline 15 & Mouse & 33 & VEH or FLX & P35-P49 & $17 \mathrm{~d}$ & HSV surgery & $3 d$ & TST \\
\hline 16 & Rat & 28 & & P47 & & HSV surgery & $3 d$ & FST \\
\hline 17 & Rat & 25 & & P47 & & HSV surgery & $3 d$ & EPM \\
\hline
\end{tabular}

mental area (VTA), a brain region implicated in mood regulation (Nestler and Carlezon, 2006; Chaudhury et al., 2013), brainderived neurotrophic factor (BDNF) and its downstream signaling effectors are compromised in preclinical models of stress (Eisch et al., 2003), as well as in postmortem VTA samples from MDD patients (Krishnan et al., 2008). Conversely, chronic administration of FLX normalizes these alterations within the VTA (Krishnan et al., 2008; Cao et al., 2010). The extracellular signalregulated kinase (ERK) 1/2, a downstream target of $\mathrm{BDNF}(\mathrm{Nu}-$ makawa et al., 2010), has been implicated in mediating the deleterious effects of stress (Gourley et al., 2008; Iñiguez et al., 2010b), a major predisposing factor for MDD (de Kloet et al., 2005). ERK is activated by the binding of BDNF to tyrosine kinase receptor- $\mathrm{B}$ via the Ras-dependent cascade, inducing phosphorylation ( $p$ ) of transcription factors such as cAMP response element-binding protein (CREB; Mazzucchelli and Brambilla, 2000). Therefore, it is conceivable that the functional effects observed in adulthood after juvenile FLX exposure may be mediated by long-lasting adaptations in ERK signaling within the VTA.

Given the prevalence of antidepressant prescriptions to adolescents and the scarcity of knowledge regarding the long-term effects of such treatments, it is essential that the neurobiological consequences associated with FLX exposure be elucidated. Thus, this study was designed to assess the impact of adolescent FLX exposure on behavioral responsivity to emotion-eliciting situations in adulthood, and to begin establishing causal relationships between the enduring FLX-induced antidepressant-like phenotype and ERK activity within the VTA.

\section{Materials and Methods}

Animals. For all experiments, animals were male, fed ad libitum, and housed at $23-25^{\circ} \mathrm{C}$ on a $12 \mathrm{~h}$ light/dark cycle (lights on between 7:00 A.M. and 7:00 P.M.). C57BL/6 mice and Sprague Dawley rats were obtained from the breeding colony at California State University, San Bernardino (CSUSB), while CD1 retired breeders were purchased from Charles River. C57BL/6 mice (four per cage), rats (two per cage), and CD1 mice (one per cage) were housed in clear polypropylene boxes containing wood shavings. Experiments were conducted in compliance with the National Institutes of Health Guide for the Care and Use of Laboratory Animals and with approval of the Institutional Animal Care and Use Committee at CSUSB.

Drug treatment and experimental design. FLX was obtained from Sigma-Aldrich, dissolved in sterile distilled water [vehicle (VEH)], and administered in a volume of $2 \mathrm{ml} / \mathrm{kg}$. The different experimental groups used in this study are listed in Table 1 . Separate groups of adolescent mice were treated with VEH or FLX (10 mg/kg, twice daily) $4 \mathrm{~h}$ apart for 15 consecutive days [postnatal day 35 (P35) to P49]. The age at the start and duration of the experimental manipulation in both mice and rats (P35P49) was selected because it roughly approximates mid-adolescence in humans (Andersen, 2003; Abreu-Villaça et al., 2010), a developmental stage in which the onset of MDD is most often reported (Burke et al., 1990; Paus et al., 2008). The drug regimen $(20 \mathrm{mg} / \mathrm{kg} / \mathrm{d})$ was selected because it yields significant effects on behavior and gene expression in rodents (Englander et al., 2005; Iñiguez et al., 2010a; LaPlant et al., 2010; Surget et al., 2011). After FLX treatment, responsiveness to behavioral despair-related (i.e., social defeat, forced swimming) and anxiety-related [i.e., elevated plus maze (EPM)] stimuli was assessed in adulthood (P70+; Table 1, groups 1-6).

To examine how FLX treatment during adolescence influenced ERK expression within the VTA, separate groups of mice and rats were treated under the same drug regimen, and killed either $24 \mathrm{~h}$ after treatment or upon reaching adulthood (groups 7-11). To assess the effects of inescapable stress on ERK signaling within the VTA, a separate group of adolescent mice was treated with VEH (P35-P49), exposed to $10 \mathrm{~d}$ of social defeat stress in adulthood (P70-P79), and killed at P80 (group 12). Also, to start building causal relationships between ERK activity and behavioral reactivity to stressors, we selectively manipulated ERK activity by infusing U0126 (Sigma-Aldrich), a pharmacological inhibitor of ERK (group 13), or a herpes simplex virus (HSV) vector encoding green fluorescent protein (GFP; control), a dominant negative mutant of ERK2 (HSV-dnERK2), or a wild-type form of ERK2 (HSV-wtERK2) within the VTA of VEH- or FLX-pretreated mice (groups 14-15; see Virus vectors and reversal experiments). Last, separate groups of P47 drug-naive rats were infused with the HSV vectors to determine whether ERK activity within the adolescent VTA modulates responsiveness to aversive stimuli (groups 16-17) in an age-dependent manner. All behaviors were video recorded and scored by video-tracking software (Noldus), except for the forced swim test (FST) and tail suspension test, which were scored by observers blind to treatment conditions.

Social defeat stress and social interaction test. Social defeat was performed as previously described (Golden et al., 2011). Resident CD1 mice consistently displaying aggressive behaviors $(<30 \mathrm{~s}$ on three screening sessions) were housed in cages fitted with perforated Plexiglas separators, which allow sensory contact without physical contact, and used to defeat the experimental mice. Specifically, adult (P70) C57BL/6 mice pretreated with VEH or FLX during adolescence (P35-P49) were exposed to a CD1 mouse for a 10-min-long defeat episode, during which time the C57BL/6 mouse was attacked and displayed subordinate posturing. To minimize physical injury and experimental animal attrition, the daily social defeat episode would be terminated immediately in the event that the CD1 

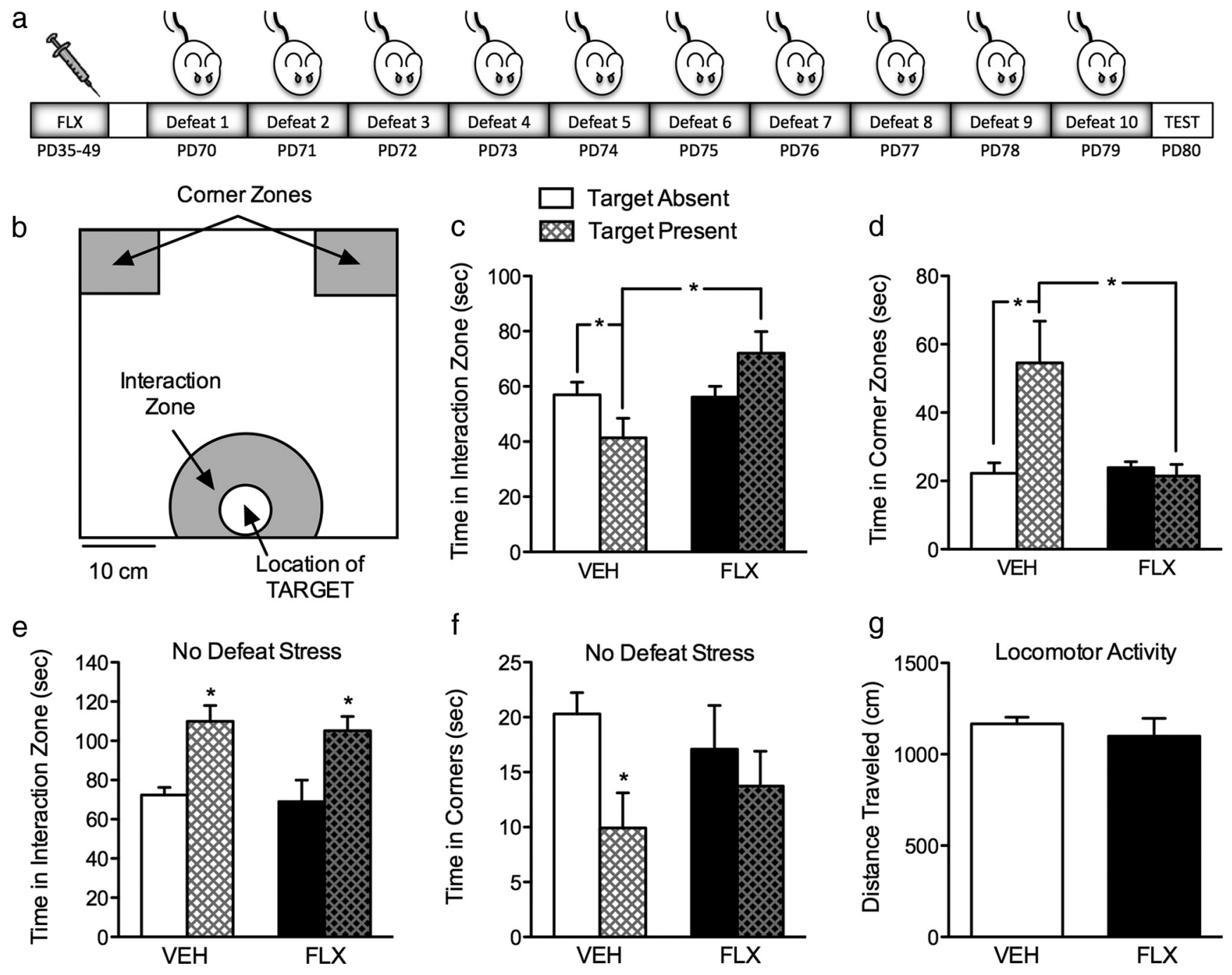

Figure 1. Enduring effects of FLX $(0,10 \mathrm{mg} / \mathrm{kg}$, bi-daily) exposure during adolescence on responsivity to social defeat stress in adulthood. $\boldsymbol{a}$, Schematic timeline of the chronic social defeat procedure in which adolescent C57BL/6 male mice were treated with FLX [postnatal day (PD)35-PD49] and were later defeated for 10 consecutive days as adults (PD70 -PD79). Mice were tested for social avoidance behaviors $24 \mathrm{~h}$ after the last defeat (PD80). $\boldsymbol{b}$, Schematic of the social interaction/avoidance arena illustrating the geographic location and size of the interaction and corner zones with respect to the enclosure in which a social target (CD1 mouse) is positioned. $c$, Mice pretreated with VEH ( $n=9)$ showed a clear avoidance phenotype $(p<0.05$; target absent vs target present), whereas mice pretreated with FLX during adolescence did not display social avoidance ( $p>0.05$; target absent vs target present) by demonstrating higher social interaction when compared with the VEH-pretreated mice $(p<0.05)$. $\boldsymbol{d}$, VEH-pretreated mice spent significantly more time in the corner zones in the presence of the target $(p<0.05)$, and when compared with the FLX-pretreated $(n=9)$ mice $(p<0.05)$. e, Baseline levels of social interaction behavior do not vary as a function of FLX pretreatment. Both VEH-pretreated $(n=7)$ and FLX-pretreated $(n=9)$ mice spent significantly more time in the interaction zone in the presence, versus the absence, of a social target $(p<0.05$, respectively). $f$, VEH-pretreated mice spent significantly less time in the corner zones in the presence, versus the absence, of the social target $(p<0.05)$. $\boldsymbol{g}$, No differences $(p>0.05)$ in distance traveled (in centimeters) were observed during the first 2.5 min of the social interaction test. Data are presented as the mean \pm SEM. ${ }^{*} p<0.05$.

mouse displayed extreme physical aggression (i.e., continuous biting after submissive posturing by the C57BL/6 mouse; for details, see Golden et al., 2011). At the end of the defeat episode, the experimental mouse was housed for the remainder of the day in the adjacent compartment next to the aggressor. This procedure was repeated for 10 consecutive days, with different aggressors used each day (Fig. 1a, schematic of experiment). Control animals were housed in pairs, with one on each side of the perforated Plexiglas partition, and were handled daily (i.e., control housing conditions). Social avoidance was assessed the following day (day 11; $\mathrm{P} 80$ ) in a two-stage social interaction test. In the first $2.5 \mathrm{~min}$ trial (target absent), a VEH- or FLX-exposed C57BL/6 mouse was allowed to freely explore a square open-field arena $(42 \times 42 \mathrm{~cm})$ containing a circular wire cage ( $9 \mathrm{~cm}$ diameter) apposed to one side (Fig. 1b). During the second 2.5 min trial (target present), the C57BL/6 mouse was reintroduced into this arena now containing a social target (unfamiliar CD1 mouse) within the circular wire cage. Time (in seconds) spent in the interaction zone $(8 \mathrm{~cm}$ corridor) and the corner zones $(10 \times 10 \mathrm{~cm})$ were the dependent variables (Berton et al., 2006).
Forced swim test. The FST is a behavioral procedure in which rodents are forced to swim under inescapable conditions. Initially, rodents engage in escape-like behaviors but eventually adopt a posture in which they make only the movements necessary to maintain their head/nose above water; however, antidepressant treatment can significantly increase their escape-directed behaviors, an effect that has been correlated with antidepressant efficacy in humans (Porsolt et al., 1977). In mice, this task was performed according to published protocols (Vialou et al., 2010; Warren et al., 2013). Briefly, mice were forced to swim once in a $4 \mathrm{~L}$ Pyrex glass beaker containing $3 \mathrm{~L}$ of water $\left(24 \pm 1^{\circ} \mathrm{C}\right)$ for $6 \mathrm{~min}$. All cylinders were emptied and cleaned between mice. For rats, this is a $2 \mathrm{~d}$ procedure. Here, rats were placed in plastic cylinders $(75 \times 30 \mathrm{~cm})$ filled to $54 \mathrm{~cm}$ depth with $24 \pm 1^{\circ} \mathrm{C}$ water and forced to swim for $15 \mathrm{~min}$. All cylinders were emptied and cleaned between rats. Twenty-four hours later, rats were retested for $5 \mathrm{~min}$ under identical conditions. At the end of each swimming period, mice and rats were removed from the water, dried with towels, and placed in a warmed enclosure for $30 \mathrm{~min}$, then returned to their home cage. For both mouse and rat forced swimming sessions, 


\section{Table 2. qPCR primers}

\begin{tabular}{|c|c|c|}
\hline Gene & Forward & Reverse \\
\hline \multicolumn{3}{|c|}{ Mouse primer sequence } \\
\hline ERK1 (Mapk3) & 5'-TCCGCCATGAGAATGTTATAGGC-3' & 5'-GGTGGTGTTGATAAGCAGATTGG-3' \\
\hline ERK2 (Mapk1) & 5' GGTTGTTCCCAAATGCTGACT-3' & 5'-CAACTTCAATCCTCTTGTGAGGG-3' \\
\hline CREB (Creb1) & 5'-AGTGACTGAGGAGCTTGTACCA-3' & 5'-TGTGGCTGGGCTTGAAC-3' \\
\hline GAPDH (Gapdh) & 5'-GTGAGAGATTTGCCAGGGTC-3' & 5'-AGAGAGAAGCCGTCAGGTTG-3' \\
\hline \multicolumn{3}{|l|}{ Rat primer sequence } \\
\hline ERK1 (Mapk3) & $5^{\prime}$-CAGCTGAGCAATGACCACAT-3' & 5'-CTTAAGGTCGCAGGTGGTGT-3' \\
\hline ERK2 (Mapk1) & $5^{\prime}$-CACAGCACCTCAGCAATGAT-3' & 5'-GTTCAGCAGCAGGTTGGAAG-3' \\
\hline CREB (Creb1) & $5^{\prime}$-GGCCTGCAGACATTAACCAT-3' & $5^{\prime}$-TCCATCAGTGGTCTGTGCAT-3' \\
\hline GAPDH (Gapdh) & $5^{\prime}$-AGCCATGTACGTAGCCATCC-3' & $5^{\prime}$-ACCCTCATAGATGGGCACAG-3' \\
\hline
\end{tabular}

latency to become immobile (in seconds) and total immobility (in seconds) were the dependent variables. Latency to immobility was defined as the time at which the animal first initiated a stationary posture that did not reflect attempts to escape from the water. To qualify as immobility, this posture had to be clearly visible and maintained for $\geq 2.0 \mathrm{~s}$. Last, for the rat FST, behavioral ( $5 \mathrm{~s}$ ) swimming and climbing counts were also quantified (Detke and Lucki, 1996; Parise et al., 2013).

Elevated plus maze. The EPM is a classic test of anxiety-like behavior (Montgomery, 1955). The mazes were made of gray plastic and consisted of two perpendicular, intersecting runways $(12 \mathrm{~cm}$ wide $\times 100 \mathrm{~cm}$ long for rats; $7 \mathrm{~cm}$ wide $\times 30 \mathrm{~cm}$ long for mice). One runway had tall walls (closed arms; $30 \mathrm{~cm}$ for rats; $25 \mathrm{~cm}$ for mice), and the other one had no walls (open arms). The arms were connected together by a central area, and the maze was elevated ( $1 \mathrm{~m}$ for rats; $50 \mathrm{~cm}$ for mice) from the floor. At the beginning of the test, under controlled light conditions ( $\sim 90$ lux), rodents were placed in the central area, facing one of the open arms, and the cumulative time spent in the closed and open arms was recorded (Iñiguez et al., 2009). We also recorded the number of fecal boli as an additional index of anxiety (Ghisleni et al., 2008).

Quantitative real-time reverse transcription PCR. Separate groups of mice and rats were killed either $24 \mathrm{~h}$ (P50) or 3 weeks (P70) after the last VEH or FLX injection. The brains were rapidly removed, VTA punches (1 mm diameter for mice; $1.25 \mathrm{~mm}$ for rats) were collected, and samples were immediately placed on dry ice and stored at $-80^{\circ} \mathrm{C}$ until assayed. Total RNA was isolated using RNEasy Micro kits (Qiagen), and cDNA was created from these samples using iScript cDNA synthesis kit (BioRad). Quantitative real-time reverse transcription PCR (qRT-reverse transcription PCR) was performed in triplicate using 96-well PCR plates and RealMasterMix (Eppendorf) with an Eppendorf MasterCycler Realplex $^{2}$ according to manufacturer's instructions. Threshold cycle $(\mathrm{Ct})$ values were measured using the supplied software and analyzed with the $\Delta \Delta$ Ct method (Vialou et al., 2010). Primer sequences for ERK1, ERK2, CREB, and glyceraldehyde-3-phosphate dehydrogenase (GAPDH) are presented in Table 2 .

Western blotting. Tissue punches of VTA (1.25 mm diameter) from adult rats (P70) pretreated with VEH or FLX during adolescence (P35P49) were collected, immediately placed on dry ice, and stored at $-80^{\circ} \mathrm{C}$ until assayed. Samples were then sonicated in a standard lysis buffer and then centrifuged at 14,000 rpm for $15 \mathrm{~min}$. Samples ( $20 \mu \mathrm{g}$; estimated via Bradford assay) were treated with $\beta$-mercaptoethanol and subsequently electrophoresed on precast $4-20 \%$ gradient gels (Bio-Rad), as previously described (Iñiguez et al., 2012). Proteins were transferred to a polyvinylidene fluoride membrane, washed in $1 \times$ Tris-buffered saline with $0.1 \%$ Tween 20 (TBST), and blocked in milk dissolved in TBST (5\% w/v) for $1 \mathrm{~h}$ at $25^{\circ} \mathrm{C}$. Blots were probed (overnight at $4^{\circ} \mathrm{C}$ ) with antibodies against the phosphorylated forms of ERK1/2, ribosomal S6 kinase of 90 $\mathrm{kDa}$ (RSK), mitogen- and stress-activated protein kinase-1 (MSK), CREB, and mammalian target of rapamycin (mTOR), stripped with Restore (Pierce Biotechnology), and reprobed with antibodies against total ERK1/2, CREB, mTOR, tyrosine hydroxylase (TH), and GAPDH. All antibodies were from Cell Signaling Technology and were used according to the manufacturer's instructions in 5\% milk dissolved in TBST. After further washes, membranes were incubated with peroxidase-labeled goat anti-rabbit IgG or horse anti-mouse IgG (1:40,000; Vector Laboratories). Bands were visualized with SuperSignal West Dura substrate (Pierce Biotechnology), quantified using NIH ImageJ, and normalized to GAPDH.
Pharmacological inhibition of ERK. To begin establishing causal relationships between ERK activity and antidepressant efficacy, separate groups of C57BL/6 mice received an infusion of the ERK inhibitor U0126 into the VTA. U0126 or dimethylsulfoxide (DMSO; 1\% in PBS; control) were delivered through an injector cannula in a total volume of $0.5 \mu \mathrm{l}$ at a continuous rate of $0.1 \mu \mathrm{l} / \mathrm{min}$. Concentration of U0126 ( $2 \mu \mathrm{g}$ dissolved in $2 \mu \mathrm{l}$ DMSO) was selected based on earlier in vivo studies (Huang and Lin, 2006). After U0126 delivery, the infusion needle remained in the guide cannula for 1 additional minute to ensure proper delivery. Mice were tested in the FST 7-8 d after cannula implantation, and $35 \mathrm{~min}$ after U0126 infusion.

Virus vectors and reversal experiments. We used HSV vectors to directly increase (HSV-wtERK2) or decrease (HSV-dnERK2) ERK activity within the VTA. The construction of the vectors (HSV-GFP, HSV-wtERK2, and HSV-dnERK2) has been thoroughly described (Robinson et al., 1996; Neve et al., 1997), and the ERK2 viruses have been previously validated in vivo and in vitro (Krishnan et al., 2007; Iñiguez et al., 2010c). All behavioral experiments were commenced $3 \mathrm{~d}$ after viral surgery, a time at which maximal transgene expression is observed (Carlezon et al., 1998; Barrot et al., 2002). Expression of the HSV-encoded transgenes was limited to an area of $\sim 1 \mathrm{~mm}^{3}$ around the injection site (see Fig. $5 b$ ), and viral expression was not apparent in either afferent or efferent regions of the injected area (Warren et al., 2011).

Because the behavioral and pharmacological experiments indicated that antidepressant-like behaviors are accompanied by decreased VTA ERK expression, we sought to more directly assess the functional significance of ERK2 activity within the VTA as a mediator of behavioral responses to inescapable stress after FLX exposure. We thus conducted two separate experiments in C57BL/6 mice exposed to VEH or FLX during adolescence and microinjected them with HSV-GFP or HSVwtERK2 in adulthood. In the first experiment (Table 1, group 14), adult mice pretreated with VEH or FLX during adolescence were microinjected with HSV-GFP or HSV-wtERK2 and exposed to a submaximal social defeat protocol (for schematic, see Fig. $5 a$ ) to examine whether increasing ERK activity would reverse the enduring antidepressant-like behavioral effects resulting from adolescent FLX exposure. In this test, mice were subjected to three defeat episodes within a single day (P69). The mice were placed into the CD1 aggressor's cage for $5 \mathrm{~min}$, followed by a $10 \mathrm{~min}$ break (in their home cage) between defeats. Each defeat episode was performed with different CD1 aggressors. This submaximal social defeat stress procedure has been successfully used to assess whether drug exposure or genetic manipulation (i.e., virus vectors) results in enhanced susceptibility to depression-like/avoidance behaviors (Krishnan et al., 2007, 2008). Social behavior was assessed $24 \mathrm{~h}$ later as described above. In the second experiment (Table 1, group 15), a separate group of VEH- or FLX-pretreated mice received HSV-GFP or HSV-wtERK2 microinjections into the VTA (P67) and were exposed to the tail suspension test (TST) 3 d later (P70) to determine whether increasing ERK2 activity would result in increased total immobility - a depression-like behavior (Steru et al., 1985). Specifically, the mice were suspended by their tail using adhesive tape (attached $\sim 2 \mathrm{~cm}$ from the tip of the tail) secured to the edge of a table in a quiet room. The duration of immobility during the 6 min test was the dependent variable. If mice climbed up their tail, they were gently returned to the hanging position; mice that climbed up the adhesive tape more than two times were excluded from the experiment. Last, we microinjected drug-naive P47 rats with the HSV vectors, and assessed their reactivity to the FST and the EPM to further examine how ERK regulation within the adolescent VTA influences behavioral responsivity to aversive circumstances (Table 1, groups 16 and 17). Here, P47 was chosen to match the FLX regimen schedule and behavioral testing at P50.

Animal surgery. Adult mice were anesthetized with a ketamine/xylazine mixture (100/10 mg/kg, i.p.) before implantation of a 26-gauge unilateral guide cannula (side counterbalanced across animals) fitted with obturators (Plastics One) that were secured to the skull after being positioned $1 \mathrm{~mm}$ directly above the VTA (anteroposterior, $-3.2 \mathrm{~mm}$; lateral, $+0.4 \mathrm{~mm}$; dorsoventral, $-3.6 \mathrm{~mm}$ ). For the viral vector studies, adult C57BL/6 mice pretreated with FLX during adolescence were anesthetized as described above, and bilaterally infused $0.5 \mu \mathrm{l}$ of either HSV- 
GFP or HSV-wtERK2 over 5 min into their VTA. We used established mouse VTA coordinates (anteroposterior, $-3.2 \mathrm{~mm}$; lateral, $+1.0 \mathrm{~mm}$; dorsoventral, $-4.6 \mathrm{~mm} ; 7^{\circ}$ angle; Krishnan et al., 2008). For stereotaxic delivery of viral vectors in adolescent rats, $\mathrm{P} 47$ rats were anesthetized with a ketamine/xylazine mixture $(90 / 10 \mathrm{mg} / \mathrm{kg}$, i.m.) and were given atropine $(0.25 \mathrm{mg} / \mathrm{kg}$, s.c.) to minimize bronchial secretions. Rats received bilateral microinjections ( $1 \mu \mathrm{l}$ per side over $10 \mathrm{~min}$ of HSV-GFP, HSV-wtERK2, or HSV-dnERK2) into the rostral region of the VTA (anteroposterior, -4.9; lateral, +2.2 ; dorsoventral, $-7.6 \mathrm{~mm}$ below dura; $10^{\circ}$ angle; Bolaños et al., 2003a). The local anesthetic bupivacaine was applied directly along the wound edges to minimize any potential postoperative discomfort. The VTA injection sites were confirmed in all animals by standard histological methods (described below).

Histology and transgene detection. Twenty-four hours after behavioral testing with the ERK inhibitor (U0126), $0.5 \mu \mathrm{g}$ of $4 \%$ methylene blue in saline was infused as described above; mice were then killed $1 \mathrm{~h}$ later, and their brains were extracted and stored in formalin for histological localization of infusion sites (see Fig. 4b). For the HSV experiments, immediately after behavioral testing, HSV-treated animals were given an overdose of pentobarbital and perfused transcardially with $0.9 \%$ saline, followed by cold 4\% paraformaldehyde. The brains were removed, postfixed overnight in 4\% paraformaldehyde, and then stored in $20 \%$ glycerol. Coronal sections (rat, $45 \mu \mathrm{m}$; mice, $30 \mu \mathrm{m}$ ) through the midbrain were obtained with a microtome and stored in $0.1 \mathrm{M}$ sodium phosphate buffer with $0.05 \%$ azide. Sections were processed to examine the ability of HSV construct to drive the expression of GFP within the VTA as previously described (Iñiguez et al., 2010b). Midbrain free-floating coronal sections were processed for immunohistochemistry using rabbit antiGFP (1:1000; Abcam) and TH (mouse; 1:5000, Millipore Bioscience Research Reagents), a marker of VTA dopamine neurons. Adjacent sections were blocked in 3\% normal donkey serum (NDS) and incubated overnight in one of the primary antibodies mentioned above, along with $0.3 \%$ Triton X-100 (Fisher Scientific) and 1\% NDS. Sections were incubated with anti-rabbit or anti-mouse secondary antibody (Jackson ImmunoResearch) for $2 \mathrm{~h}$ at room temperature. Stained sections were then slide mounted (Fisher Scientific), dehydrated in ethanol, defatted in Citrosolv, and coverslipped with clear DPX adhesive (Sigma-Aldrich). Slides were then visualized and photographed using a fluorescence microscope and a digital camera. The total number of GFP-labeled cells throughout the VTA was determined in every sixth brain slice, and the percentage of those cells that coexpressed TH was calculated. Data obtained from animals with placements outside the intended brain regions $(<10 \%$ of all experimental animals) were not included in the analyses.

Statistical analyses. Assignment of subjects to the various experimental conditions was random. Behavioral data were analyzed using ANOVA techniques, with drug, defeat stress, and virus as independent variables, and the presence of target as a repeated measure, followed by Tukey's post hoc test. A $t$ test, consisting of only a two-group comparison, was used for all other analyses. Statistical significance was defined as $p<0.05$. Data are expressed as the mean + SEM.

\section{Results}

Adolescent FLX exposure regulates behavioral responses to aversive situations in adulthood

Social defeat stress

Figure 1, $c$ and $d$, shows the effects of FLX treatment during adolescence on social interaction after exposure to defeat stress in adulthood ( $n=9$ per group). Mice pre-exposed to VEH and FLX were subjected to $10 \mathrm{~d}$ (P70-P79) of social defeat (Fig. 1a), a stress regimen that induces a robust social avoidance in the majority of mice (Krishnan et al., 2007). Consistently, $24 \mathrm{~h}$ after the last defeat (P80), a two-way ANOVA revealed a significant drug pretreatment (VEH vs FLX) by the presence of social target (present vs absent) interaction $\left(F_{(1,16)}=6.41, p<0.02\right)$ with the time spent in the interaction zone. Post hoc comparisons indicated that the social avoidance phenotype was evident in the VEHpretreated mice, as they spent significantly less time in the inter- action zone (Fig. 1c) in the presence of the social target (target absent vs target present, $p<0.05$ ). On the contrary, mice pretreated with FLX during adolescence spent as much time in the interaction zone in the absence, as in the presence, of the social target $(p>0.05)$, suggesting that exposure to FLX early in life buffered the development of the stress-induced social avoidance phenotype in adulthood. Indeed, the FLX-pretreated mice spent significantly more time in the interaction zone when compared with the VEH-pretreated controls in the presence of the social target (between-group comparison, $p<0.01$; Fig. 1c). Assessing time in the corner zones (Fig. 1d), an additional measure of social avoidance (Krishnan et al., 2007), yielded similar results (drug pretreatment by the presence of target interaction, $F_{(1,16)}=6.26$, $p<0.02)$; VEH-pretreated mice spent significantly more time in the corners in the presence of the target (target absent vs present, $p<0.01)$ or when compared with the FLX-pretreated group (between-group comparison, $p<0.01$ ).

To examine how FLX exposure during adolescence would influence baseline social interaction behavior in adulthood (in the absence of defeat stress), a second group of mice was exposed to $\mathrm{VEH}(n=7)$ or FLX $(n=9)$ from P35 to P49, was later housed under control conditions for $10 \mathrm{~d}$ (P70-P79), and then tested for social interaction at P80. A two-way (drug pretreatment $\times$ target) ANOVA revealed a significant main effect of target presence $\left(F_{(1,14)}=33.29, p<0.0001\right)$ on the time spent in the interaction zone (Fig. 1e). Here, both VEH- and FLX-pretreated mice spent significantly more time in the interaction zone in the presence of the social target (within-group comparison, $p<0.05$, respectively). When assessing the time spent in the corner zones (Fig. $1 f)$, a significant main effect of target presence $\left(F_{(1,14)}=7.20, p<\right.$ $0.01)$ indicated that the VEH-pretreated mice spent significantly less time in the corner zones in the presence of the social target (target absent vs target present, $p<0.05$ ). No differences in time spent in the corners were observed in the FLX-pretreated mice (target absent vs target present, $p>0.05$ ). Lastly, no differences in total distance traveled (in centimeters) were observed between the groups $(p>0.05)$ as a function of FLX pretreatment during the target-absent condition (Fig. $1 g$ ).

\section{Forced swim stress}

Similar to the results observed in the social defeat stress procedure, FLX exposure during adolescence prevented the expression of depression-like responses in adulthood (P70) as indexed in the FST (Fig. 2a,b). Exposure to FLX during adolescence resulted in a significant increase in the latency to become immobile $\left(t_{(17)}=\right.$ $3.89, p<0.001$; Fig. $2 a$, left) and an overall decrease in total immobility $\left(t_{(17)}=2.27, p<0.03\right.$; Fig. $2 a$, right) when compared with the VEH-pretreated controls ( $n=9-10$ per group). Next, we examined whether FLX exposure during adolescence would induce antidepressant-like effects in the FST following an even more chronic form of inescapable stress. Here, separate groups of mice were exposed to VEH $(n=8)$ or FLX $(n=10)$ from P35 to $\mathrm{P} 49$, and both sets of mice received $10 \mathrm{~d}$ of social defeat stress 3 weeks later (P70-P79). Twenty-four hours after the last defeat (P80), these mice were exposed to the FST (Fig. 2b). Again, we found that FLX pretreatment resulted in an overall antidepressant-like effect as inferred by an increase in latency to immobility $\left(t_{(16)}=2.48, p<0.05\right.$; Fig. $2 b$, left $)$, along with a decrease in total immobility $\left(t_{(16)}=2.80, p<0.001\right.$; Fig. $2 b$, right) when compared with VEH-pretreated mice.

\section{Elevated plus maze}

FLX exposure during adolescence resulted in a significant increase in sensitivity to the anxiety-eliciting environment of the 
a

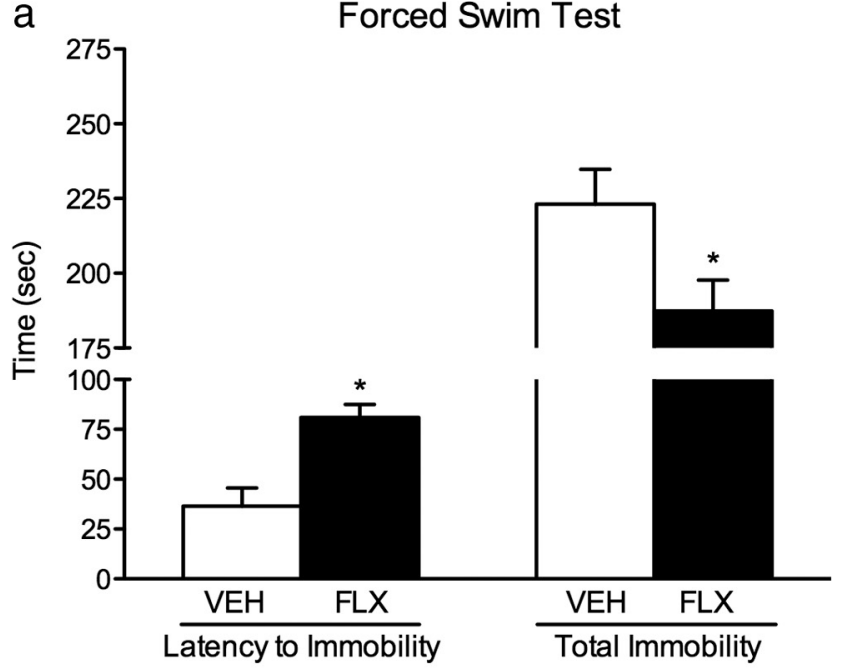

b Forced Swim Test post Social Defeat

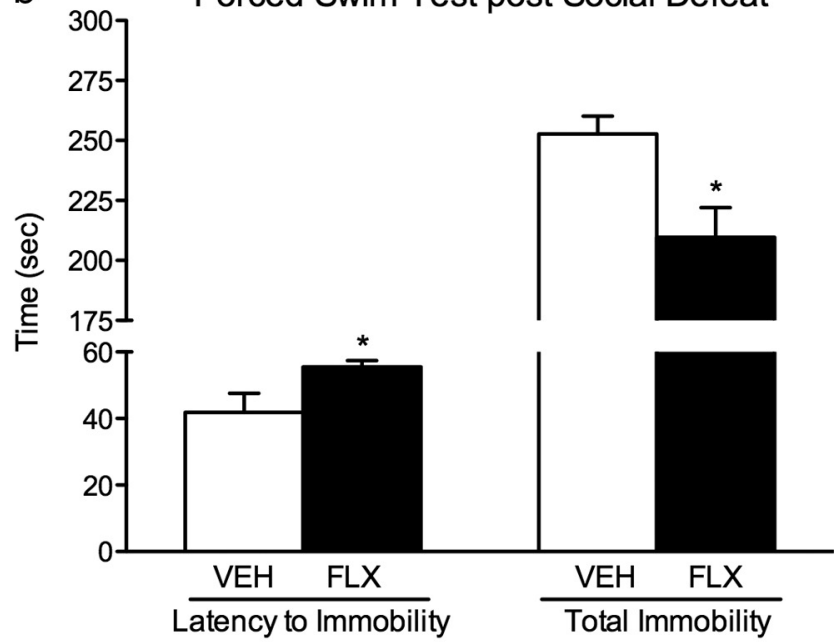

C

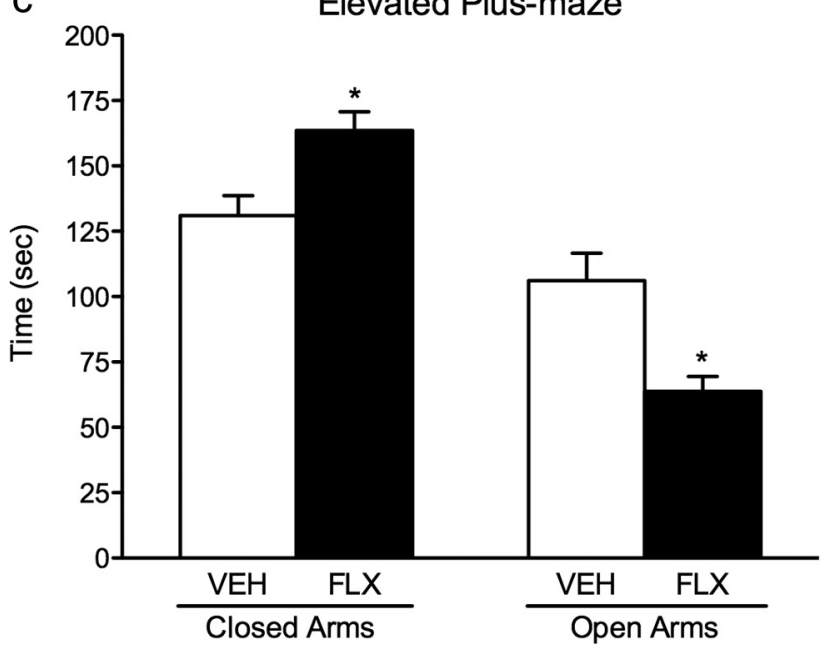

Figure 2. Enduring effects of $F L X(0,10 \mathrm{mg} / \mathrm{kg}$, bi-daily) exposure during adolescence (P35P49) on responsivity to forced swimming stress and anxiety-inducing environments in adulthood. $\boldsymbol{a}$, Forced swim test: mice exposed to $\mathrm{FLX}(n=9)$ during adolescence displayed a higher latency to become immobile (left) and an overall decrease in total immobility (right), when compared with the VEH-pretreated mice $(n=10 ; p<0.05)$. $\boldsymbol{b}$, This enduring FLX-induced antidepressant-like effect was also evident after a more chronic exposure to inescapable stress in adulthood (i.e., exposure to forced swimming stress after $10 \mathrm{~d}$ of social defeat). FlXpretreated mice $(n=10)$ exposed to social defeat stress from P70 to P79 displayed higher
EPM in adulthood (Fig. $2 c ; n=10$ per group). Mice pre-exposed to FLX as adolescents spent more time in the closed arms $\left(t_{(18)}=\right.$ $3.09, p<0.006)$ and less time in the open arms $\left(t_{(18)}=3.53, p<\right.$ $0.002)$ of the EPM as adults when compared with the VEHpretreated controls. No differences in total distance traveled (in centimeters) during the 5 min test were observed between the groups ( $p>0.05$; data not shown). To further explore whether adolescent FLX would influence responses to the EPM following a more chronic form of inescapable stress in adulthood, separate groups of mice were exposed to VEH $(n=9)$ or FLX $(n=10)$ from P35 to P49. Twenty-one days later, both sets of mice were exposed to $10 \mathrm{~d}$ of social defeat stress (P70-P79), and $24 \mathrm{~h}$ after the last episode of defeat, these mice were tested in the EPM (P80). No differences in the time spent in the open or closed arms of the maze were detected between the groups as a function of drug pretreatment ( $p>0.05$, respectively). These findings suggest that adolescent FLX pre-exposure does not influence responses to the EPM after $10 \mathrm{~d}$ of social defeat stress in adulthood (data not shown).

\section{Opposing role between FLX and stress on ERK signaling within the VTA}

We then assessed the effects of FLX administration during adolescence on gene expression within the VTA, $24 \mathrm{~h}$ (short-term; $n=8$ per group) and 3 weeks (long-term; $n=8-9$ per group) after drug administration in C57BL/6 mice (Fig. $3 a-c$ ). No differences in ERK1 mRNA as a function of FLX treatment were observed at either short- or long-term points of assessment ( $p>$ 0.05 , respectively; Fig. $3 a$ ). Conversely, chronic administration of FLX decreased ERK2 $\left(t_{(14)}=2.72, p<0.01\right)$ and CREB $\left(t_{(14)}=\right.$ $2.46, p<0.01)$ mRNA $24 \mathrm{~h}$ after the last injection (Fig. $3 b, c$, left), when compared with the VEH-pretreated mice. Three weeks after the last FLX injection (P70), decreases in ERK2 $\left(t_{(15)}=2.28\right.$, $p<0.05$; Fig. $3 b$, right $)$ and CREB $\left(t_{(15)}=1.7, p=0.056\right) \mathrm{mRNA}$ were observed when compared with the VEH-pretreated mice (Fig. 3c, right).

To determine the effect of stress in the absence of adolescent FLX treatment on ERK mRNA within the VTA, two separate groups of mice ( $n=7$ per group) were treated with VEH during adolescence and, as adults (P70-79), were either exposed to $10 \mathrm{~d}$ of social defeat stress or left undisturbed. Twenty-four hours after the last social defeat episode (P80), mice were killed and VTA was extracted and processed for qRT-reverse transcription PCR. No differences in ERK1 mRNA (Fig. 3d) were detected between stressed (social defeat) and nonstressed (control) mice $(p>$ $0.05)$. On the other hand, defeated mice exhibited increased ERK2 mRNA $\left(t_{(12)}=4.92, p<0.01\right)$ when compared with the nondefeated controls (Fig. 3e). Together, these findings indicate that FLX and stress regulate ERK2 mRNA within the VTA in an opposing manner.

Functional role of ERK within the VTA in regulating moodrelated behaviors

To more directly explore whether decreasing ERK activity within the VTA results in a similar antidepressant-like behavioral profile

$\leftarrow$

latencies to immobility $(p<0.05$; left) and decreased time spent immobile $(p<0.05$; right), when compared with the defeated VEH-pretreated mice $(n=8)$.c, Mice exposed to FLX during adolescence $(n=10)$ spent significantly more time in the closed arms ( $p<0.05$; left) and less time in the open arms $(p<0.05$; right) of the elevated plus maze when compared with VEH-pretreated mice $(n=10)$. Data are presented as the mean \pm SEM. ${ }^{*} p<0.05$. 

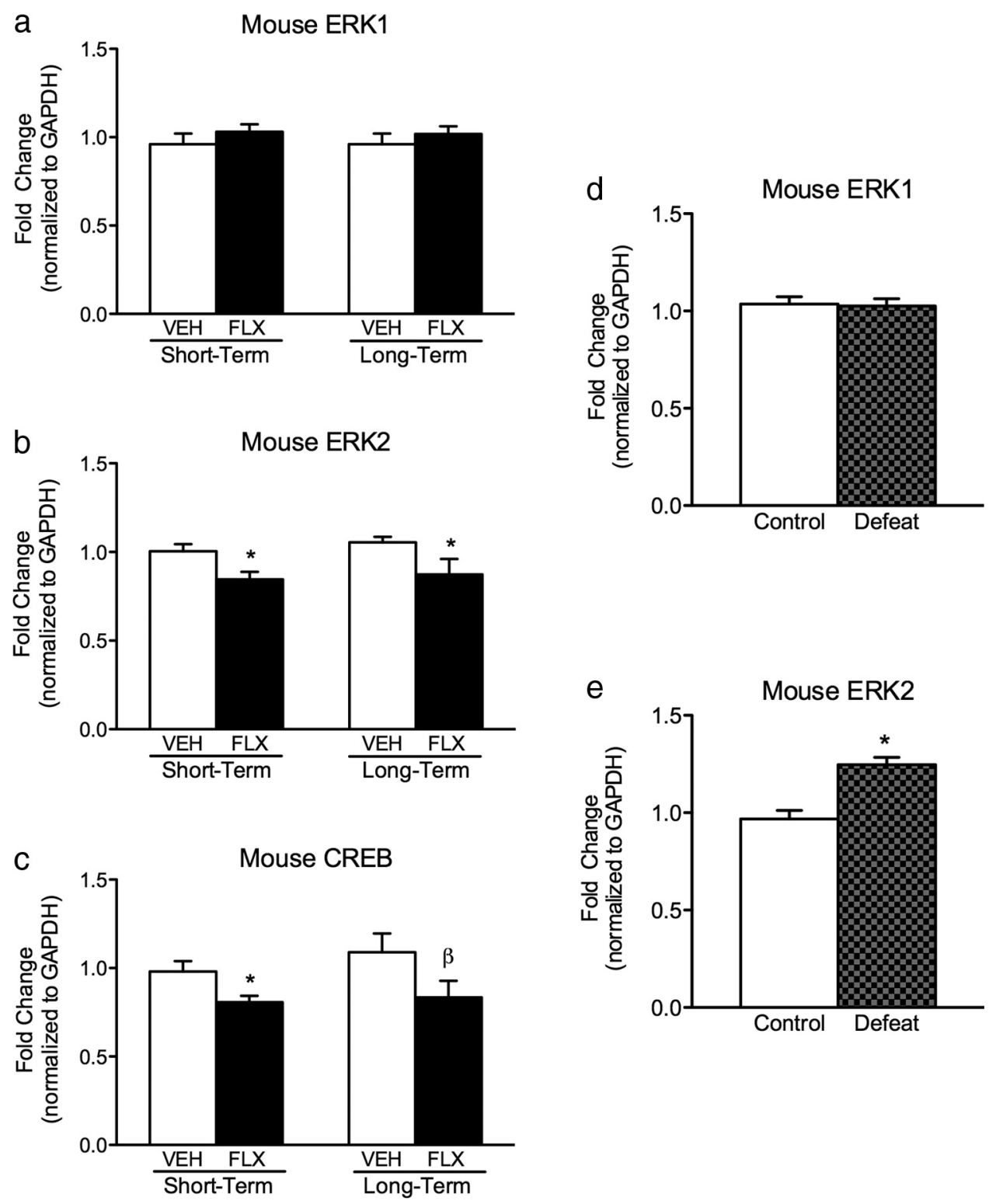

Figure 3. Regulation of ERK mRNA within the VTA of C57BL/6 male mice exposed to FLX and mice exposed to social defeat stress. $a-c$, Chronic FLX exposure $(0,10 \mathrm{mg} / \mathrm{kg}$, bi-daily) during adolescence reduced ERK2 and CREB, but not ERK1, mRNA $24 \mathrm{~h}$ (short term; $n=8$ per group) or $21 \mathrm{~d}$ (long term; $n=8-9$ per group) after drug exposure when compared with the respective VEH-pretreated controls. $\boldsymbol{d}, \boldsymbol{e}$, Exposure to $10 \mathrm{~d}$ of social defeat stress significantly increased ERK2, but not ERK1, mRNA when compared with the nonstressed controls ( $n=7$ per group). Data are presented as the fold change normalized to GAPDH \pm SEM. ${ }^{*} p<0.05 ; \beta p=0.056$.

as FLX administration, separate groups of mice were locally infused with DMSO (control; $n=11$ ) or the ERK inhibitor U0126 into the VTA $(n=15)$, and were tested $35 \mathrm{~min}$ after infusion in the FST (Fig. 4). The infusion cannula tip locations are schematically depicted in Figure 4, $a$ and $b$. Mice infused with U0126 showed significantly longer latency to immobility $\left(t_{(24)}=2.39\right.$, $p<0.05$; Fig. $4 c$ ), as well as a significant decrease in total immobility $\left(t_{(24)}=2.31, p<0.05\right.$; Fig. $\left.4 d\right)$ when compared with the DMSO-infused controls, thus displaying a classic antidepressantlike effect (Porsolt et al., 1977).

\section{Reversal of the enduring FLX-induced antidepressant} behavioral phenotype in adulthood

Based on our findings that FLX exposure during adolescence decreases sensitivity to social defeat and forced swimming stress, along with decreases in ERK2 activity within the VTA in adulthood, it was of interest to assess whether locally increasing ERK2 activity within this brain region would reverse this effect, thus increasing sensitivity to behavioral despair (Fig. 5). To this end, adult C57BL/6 mice pretreated with VEH or FLX as juveniles received a local microinjection of HSV-GFP or HSV-wtERK2 within the VTA, and their social behavior was assessed after a submaximal period of social defeat stress (Fig. 5a) - a stress regimen that is not sufficient to induce social avoidance in control mice (Krishnan et al., 2008). A three-way (drug $\times$ virus $\times$ target) ANOVA revealed a significant virus by target interaction for the time spent in the interaction zone $\left(F_{(1,68)}=16.57, p<0.0001\right)$. As expected, $\mathrm{VEH}$-pretreated mice receiving microinjections of HSV-GFP (VEH+GFP; $n=9$ ) did not differ in the time spent in the interaction zone (Fig. $5 c$ ), in the absence or presence of the social target $(p>0.05)$, thus indicating that submaximal social defeat was not sufficient to induce social avoidance in control mice, as previously reported (Krishnan et al., 2008; Iñiguez et al., 2010b). On the contrary, VEH-pretreated mice overexpressing 
HSV-wtERK2 $(n=9)$ spent significantly less time in the interaction zone (Fig. $5 c$ ) in the presence of the social target $(p<$ $0.05)$, or when compared with the VEHpretreated mice expressing HSV-GFP $(p<0.01)$. Time spent in the corner zones (Fig. $5 d$ ) varied as a function of a virus by the presence of target interaction $\left(F_{(1,68)}=18.73, p<0.001\right)$. VEHpretreated mice expressing HSV-wtERK2 spent significantly more time in the corners in the presence of the social target $(p<0.05)$, whereas those pretreated with FLX and microinjected with HSV-GFP $(n=11)$ spent significantly less time in the corner zones (Fig. $5 d$ ) in the presence of the social target $(p<0.05)$. Conversely, FLX-pretreated mice overexpressing HSVwtERK2 $(n=9)$ spent significantly less time in the interaction zone in the presence of the target ( $p<0.05$; Fig. $5 c)$, or when compared with FLX-pretreated mice expressing HSV-GFP $(p<0.05)$. These mice also spent significantly more time in the corners in the presence of the target $(p<0.05$; Fig. $5 d$ ) or when compared with FLXpretreated mice expressing HSV-GFP $(p<$ $0.03)$. Together, this indicates that elevated ERK2 activity within the VTA enhances sensitivity to defeat stress, regardless of FLX pretreatment during adolescence. Importantly, no differences in distance traveled (in centimeters) were observed between the groups as a function of drug pretreatment or virus infusion $(p>$ 0.05 ) during the target-absent session (Fig. 5e).

To further delineate the role of increased ERK2 activity within the VTA in modulating responsiveness to other behavioral despair measures, we microinjected HSV-GFP or HSV-wtERK2 into the VTA of adult mice pretreated with VEH or FLX during adolescence, and assessed their behavioral reactivity to the TST (VEH+GFP, $n=8$; VEH + wtERK2, $n=8$; FLX + GFP, $n=8$; or FLX + wtERK2, $n=9$ ). A two-way (drug $\times$ virus) ANOVA revealed that the total time spent immobile on the TST was dependent on virus treatment $\left(F_{(1,29)}=39.30, p<0.0001\right)$, regardless of FLX pretreatment (drug main effect, $p>0.05$; Fig. 5f). Specifically, mice overexpressing HSV-wtERK2 displayed greater immobility time (i.e., prodepressant effect) when compared with the HSV-GFP-microinjected mice. Planned comparisons revealed that FLX-pretreated mice expressing HSV-GFP spent significantly less time immobile when compared with the VEH-pretreated mice overexpressing HSVGFP $(p<0.05)$, thus further confirming the enduring FLXinduced effect observed in the social defeat and FST paradigms (Figs. 1c, $d, 2 a, b)$.

\section{Developmental role of ERK within the VTA in responses to aversive stimuli}

Our data thus far indicate that repeated exposure to FLX during adolescence (P35-P49) results in decreased sensitivity to behavioral despair along with increased reactivity to anxiety-eliciting situations in adulthood. Our results also point to decreased ERK2 signaling within the VTA as a potential mediator of these lasting FLX-induced effects. To further compliment the present results, we examined the role of ERK activity within the adolescent VTA in modulating responses to stress. Accordingly, we assessed the influence of FLX on ERK signaling (mRNA and protein phosphorylation), and directly assessed the functional role of ERK in modulating responsiveness to stressful circumstances, using HSV vectors in adolescent rats.

\section{Effects of FLX exposure during adolescence on ERK $m R N A$ in the} rat VTA

Adolescent rats were exposed to VEH or FLX from P35 to P49 and killed either $24 \mathrm{~h}$ ( $n=9$ per group; short-term) or 3 weeks $(n=7-8$ per group; long-term) after drug exposure (Fig. $6 a-c)$. Similar to our findings in C57BL/6 mice, FLX exposure did not influence ERK1 mRNA at any of the time points assessed (Fig. 6a). Conversely, FLX exposure significantly decreased ERK2 mRNA at $24 \mathrm{~h}\left(t_{(16)}=2.02, p<0.03\right)$ and 3 weeks $\left(t_{(13)}=2.05\right.$, $p<0.05)$ after drug administration when compared with the VEH-pretreated controls (Fig. 6b). FLX also decreased CREB mRNA (Fig. $6 c$ ), a downstream signaling substrate of ERK, at the short-term $\left(t_{(16)}=2.31, p<0.01\right)$ and long-term $\left(t_{(13)}=2.21\right.$, $p<0.05)$ points of assessment, when compared with the VEHpretreated controls.

\section{Enduring effects of FLX exposure during adolescence on} ERK-related protein phosphorylation in the rat VTA

We also examined ERK protein phosphorylation and related targets in a separate group of adult rats exposed to FLX during adolescence (Fig. 7). ERK-related signaling was assessed 3 weeks after VEH or FLX exposure ( $n=8$ per group), as inferred from the $\mathrm{p}$ levels of ERK1/2, as well as its downstream targets, RSK, MSK, CREB, and mTOR, within the VTA (Fig. 7a). FLX- 

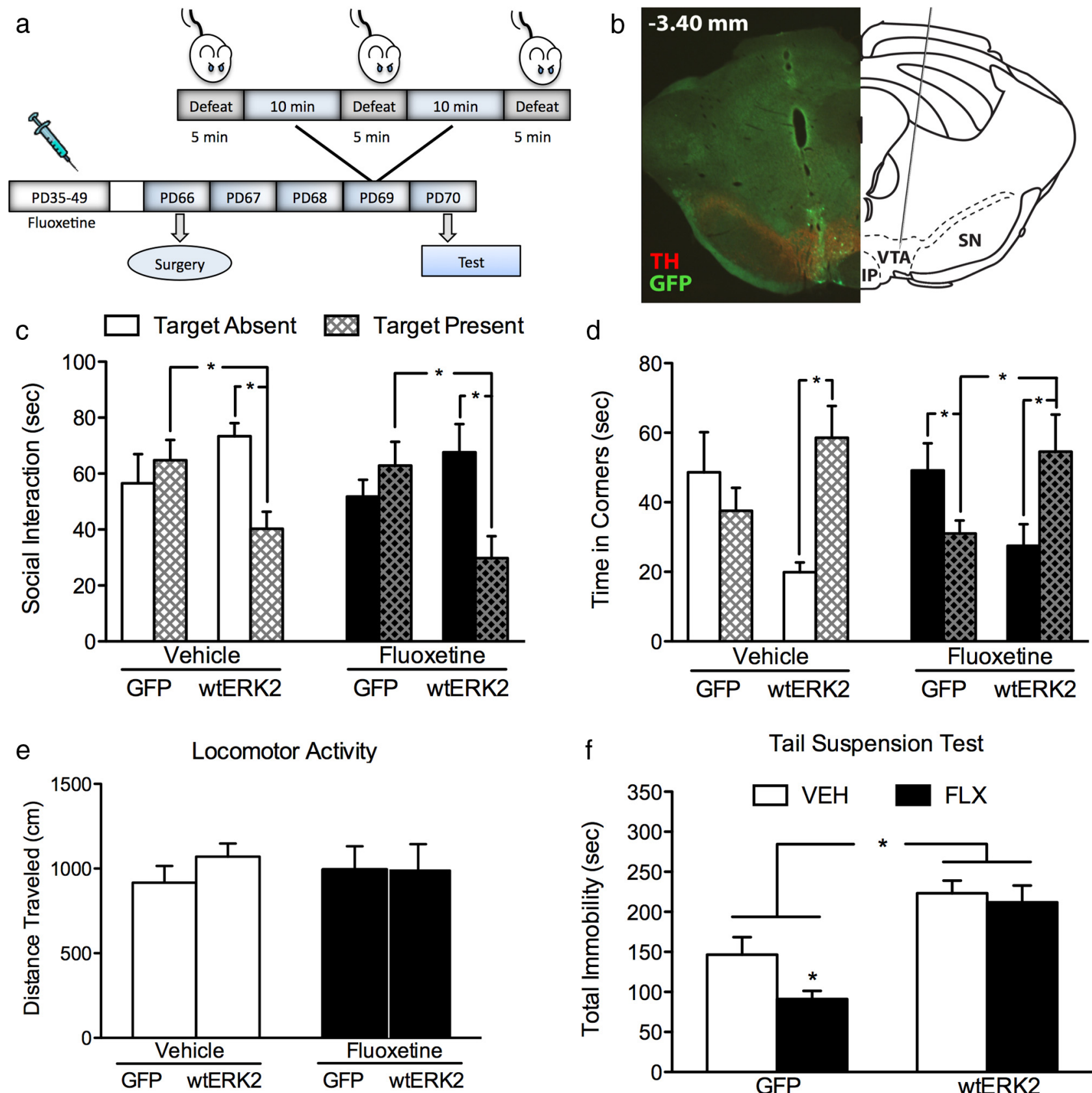

f

\section{Tail Suspension Test}

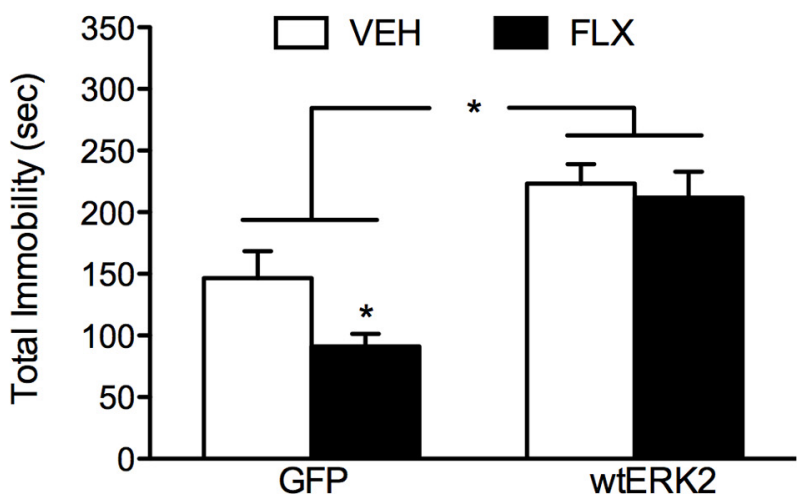

Figure 5. Viral-mediated upregulation of ERK2 within the VTA of adult C57BL/6 mice reverses the enduring antidepressant-like effects of FLX exposure during adolescence. $\boldsymbol{a}$, Schematic timeline of the submaximal social defeat procedure in which C57BL/6 male mice were pretreated with VEH or FLX (10 mg/kg, bi-daily) during adolescence [postnatal day (PD)35-PD49] and later (PD66) received an infusion of HSV-GFP ( $n=9-11$ per group) or HSV-wtERK2 ( $n=9$ per group) in adulthood. Three days later (P69), the mice were socially defeated three times (5 min each) in a single day and were tested on the social interaction test $24 \mathrm{~h}$ later (PD70). $\boldsymbol{b}$, Viral-mediated gene transfer. Representative fluorescence photomicrograph displaying the expression of TH (red; cyanine 3 ) and GFP (green; cyanine 2) within the targeted VTA ( $\sim 3.40 \mathrm{~mm}$ caudal from bregma; Franklin and Paxinos, 2008). IP, Interpeduncular nucleus; SN, substantia nigra. c, $\boldsymbol{d}$, No differences were detected in the time spent in the interaction zone (c, left) or corner zones (d, left) in the presence or absence of the social target in mice pretreated with VEH during adolescence and later infused with HSV-GFP in adulthood, thus indicating that the submaximal defeat stress schedule was not sufficient to induce social avoidance in control mice. Conversely, FLX-pretreated mice infused with HSV-wtERK2 spent significantly less time in the interaction zone (c, right) as well as more time in the corners (d, right) in the presence, versus the absence, of the social target. Infusion of HSV-wtERK2 in adulthood, regardless of adolescent drug pretreatment, resulted in social avoidance, thus reversing the enduring antidepressant-like effects of FLX on social behavior. $\boldsymbol{e}$, No differences in locomotor activity were observed as a function of adolescent drug pretreatment or virus infusion in adulthood. $f$, In the tail suspension test, selectively increasing ERK2 within the VTA via HSV-wtERK2 ( $n=8-9$ per group) results in enhanced vulnerability to stress (i.e., increased immobility), regardless of drug pretreatment (right), when compared with the HSV-GFP-treated mice ( $n=8$ per group). Conversely, mice pretreated with FLX and infused with HSV-GFP (left) displayed decreased total immobility (in seconds) when compared with VEH + GFP controls. Data are presented as the mean \pm SEM. ${ }^{*} p<0.05$.

pretreated rats had a significant decrease in pERK2 $\left(t_{(14)}=1.89\right.$, $p<0.04), \operatorname{pRSK}\left(t_{(14)}=3.28, p<0.01\right), \operatorname{pCREB}\left(t_{(14)}=1.87, p<\right.$ $0.04)$, and pmTOR $\left(t_{(14)}=4.91, p<0.01\right)$, while having no effects on pERK1 $(p>0.05)$ and pMSK $(p>0.05)$, when compared with the VEH-pretreated controls. No changes in total protein levels of ERK1, ERK2, CREB, or mTOR $(p>0.05$, respectively; Fig. 7b) were detected when compared with VEH-pretreated controls (all normalized to GAPDH). To ensure consistency across the VTA samples collected, we also compared TH levels, a common marker for dopamine neu- 


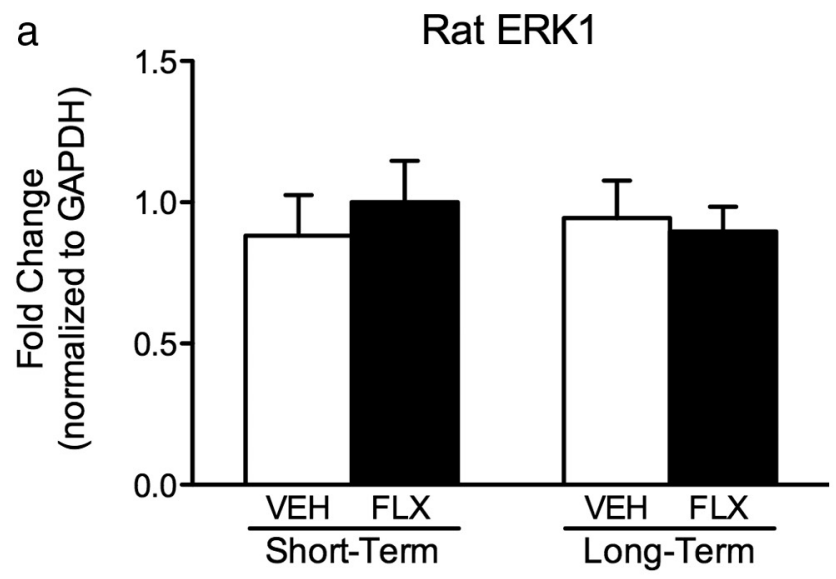

b
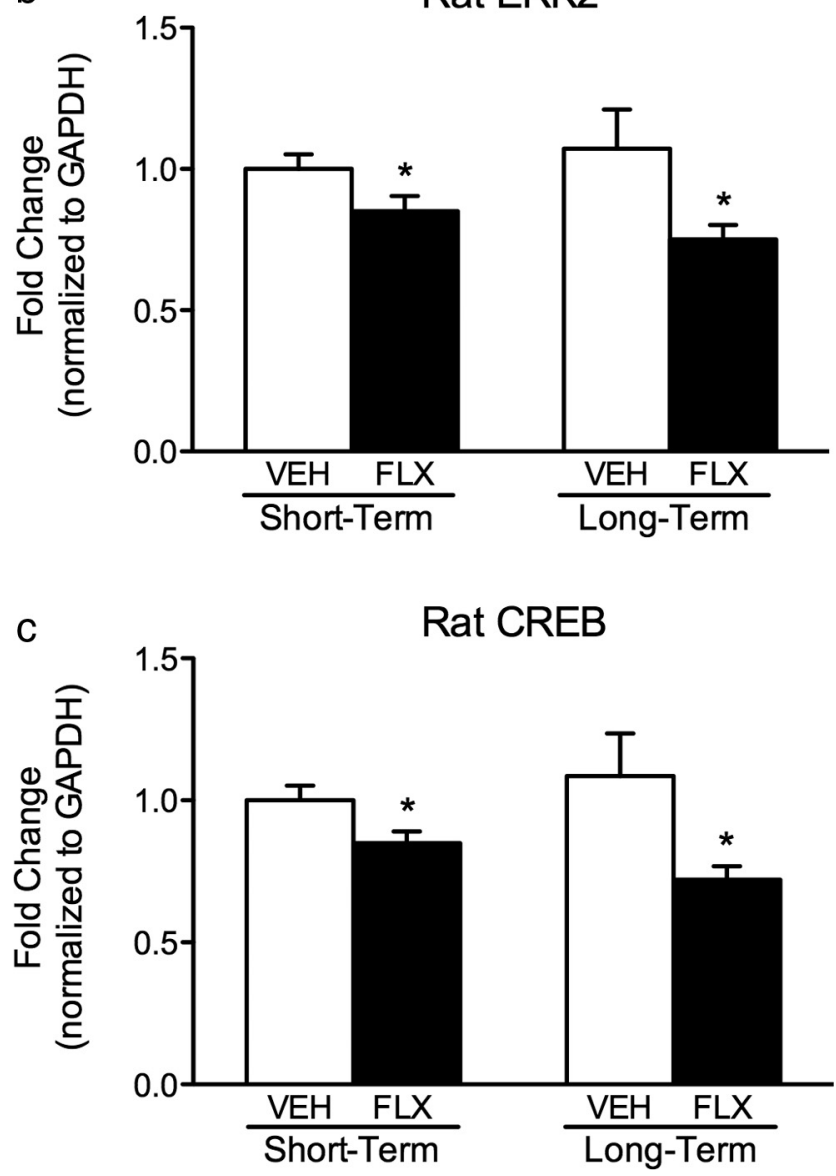

Figure 6. Effects of VEH or FLX ( $10 \mathrm{mg} / \mathrm{kg}$, bi-daily) exposure during adolescence on mRNA expression within the VTA of male rats. $\boldsymbol{a}-\boldsymbol{c}$, Exposure to FLX during adolescence resulted in no changes in ERK1 mRNA (a), while significantly decreasing ERK2 (b) and CREB (c) mRNA $24 \mathrm{~h}$ (short term; $n=9$ per group) or $21 \mathrm{~d}$ (long term; $n=7-8$ per group) after the last drug injection when compared with VEH-pretreated controls. Data are presented as the fold change normalized to GAPDH \pm SEM. ${ }^{*} p<0.05$.

rons (Fig. $7 b$ ), and found no differences in total $\mathrm{TH}$ between the groups $(p<0.05)$.

Validation of virus-mediated gene transfer in the adolescent VTA Figure $8 a$ shows the region of the anterior portion of the VTA to which virus vectors (HSV-GFP, HSV-wtERK2, HSV-dnERK2) were aimed (Paxinos and Watson, 1997). We found that HSV transgene expression was maximal on day 3 after infusion (data not shown), declining thereafter, and nondetectable $7 \mathrm{~d}$ after the microinjection, as previously shown in adults (Iñiguez et al., 2010b; Warren et al., 2011). Confocal microscopy (Fig. 8b-d) revealed that the percentage of $\mathrm{TH}$-positive neurons overexpressing GFP in the VTA (57\%) was similar to previous findings (Iñiguez et al., 2008b, 2010b,c).

Virus-mediated ERK2 expression in the adolescent rat VTA modulates reactivity to aversive situations

Microinfusions of HSV-GFP $(n=10)$, HSV-wtERK2 $(n=9)$, and HSV-dnERK2 $(n=9)$ within the VTA influenced behavioral reactivity to forced swimming stress in adolescent rats (Fig. 8e,f). The amount of time rats engaged in escape-directed behaviors varied as a function of virus treatment (latency to immobility, $F_{(2,25)}=23.37, p<0.001$; Fig. 8e). HSV-wtERK2-treated rats displayed shorter latencies to immobility when compared with the HSV-GFP-treated controls $(p=0.051)$. Conversely, adolescent rats receiving HSV-dnERK2 displayed longer latencies to immobility when compared with the HSV-GFP-treated rats $(p<0.05)$. Virus treatment also influenced total immobility $\left(F_{(2,25)}=13.51, p<0.01\right.$; Fig. $\left.8 f\right)$, with HSV-wtERK2 showing higher (i.e., increased sensitivity to behavioral despair) and HSV-dnERK2-treated rats showing lower (i.e., decreased sensitivity to behavioral despair) total immobility when compared with the HSV-GFP-treated controls $(p<0.05$, respectively). No differences in swimming or climbing counts, as a function of virus treatment, were observed between the groups ( $p>0.05$, respectively; data not shown).

We also assessed the ability of ERK2 to modulate anxiety-like behaviors, as measured in the EPM ( $n=8-9$ per group; Fig. 9). Time spent in the closed arms of the maze varied as a function of virus treatment $\left(F_{(2,22)}=18.86, p<0.001\right)$. Adolescent rats microinjected with HSV-wtERK2 spent significantly less time in the closed arms $(p<0.05)$, whereas those receiving HSV-dnERK2 spent significantly more time in the closed arms $(p<0.05)$ when compared with the HSV-GFP-treated controls (Fig. 9a). Similarly, a one-way ANOVA revealed that time spent in the open arms (Fig. 9b) also varied as a function of virus treatment $\left(F_{(2,22)}\right.$ $=10.43, p<0.001)$. Adolescent rats receiving HSV-wtERK2 spent significantly more time in the open arms when compared with the HSV-GFP-treated controls $(p<0.05)$, while no differences were observed between the HSV-GFP and HSV-dnERK2 groups $(p>0.05)$. The number of fecal boli was also quantified as an additional index of anxiety (Fig. $9 c$ ). Here, the number of fecal boli was also influenced by viral treatment $\left(F_{(2,22)}=14.68, p<\right.$ $0.01)$. HSV-dnERK2-treated rats produced more fecal boli when compared with the HSV-GFP-treated controls $(p<0.05)$. Conversely, rats infused with the HSV-wtERK2 virus produced significantly fewer fecal boli than the HSV-GFP-treated controls $(p<0.05)$. No differences in total distance traveled (in centimeters) were observed between groups as a function of virus treatment ( $p>0.05$; Fig. $9 d)$.

\section{Discussion}

Antidepressants are often prescribed to juveniles for the treatment of MDD (Safer, 2006), even though reliable evidence-based indications for their use and the neurobiological consequences of such treatments are lacking (Birmaher, 1998; Coyle et al., 2003). Thus, the present study was designed to assess enduring behavioral and biochemical consequences resulting from adolescent exposure to FLX. We show that chronic FLX administration during adolescence alters responsiveness to aversive circumstances while disrupting VTA ERK2 expression and related signaling in 
a

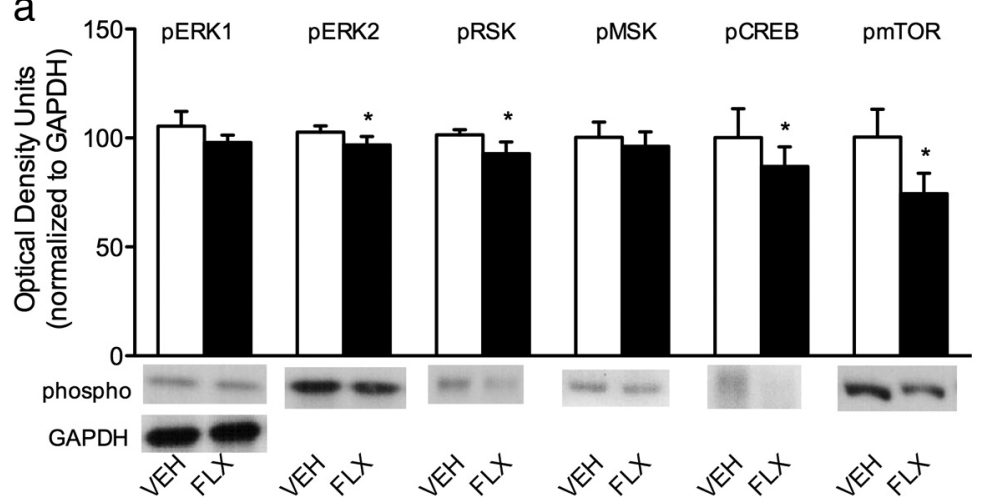

b

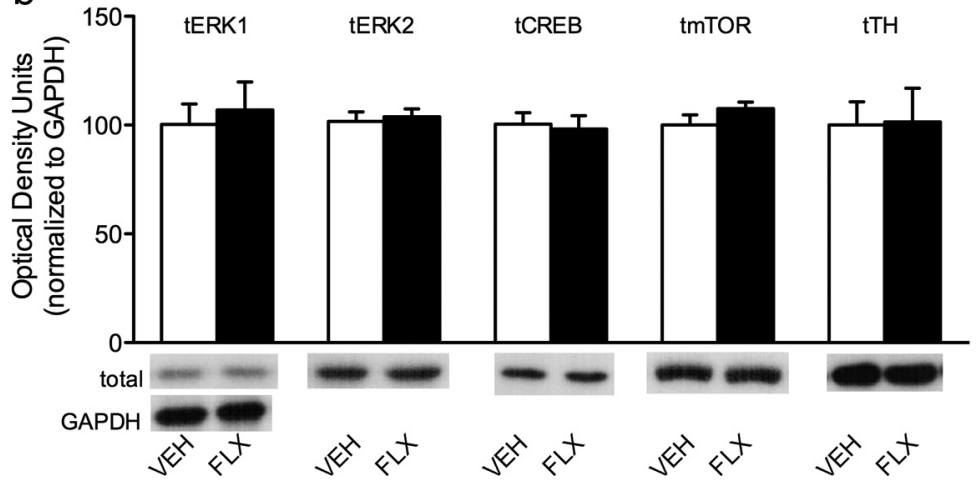

Figure 7. Long-term effects of exposure to VEH or FLX ( $10 \mathrm{mg} / \mathrm{kg}$, bi-daily) during adolescence on ERK-related protein phosphorylation within the VTA of male rats ( $n=8$ per group). $\boldsymbol{a}, \boldsymbol{b}$, Exposure to FLX during adolescence significantly decreased the levels of pERK2, pRSK, pCREB, and pmTOR ( $p<0.05$, respectively), but not pERK1 or pMSK (a), without affecting levels of total ( $\mathrm{t}$ ) protein (tERK1, tERK2, tCREB, tmTOR, and tTH; $\boldsymbol{b}$ ) when compared with the VEH-pretreated controls. Data are presented as a ratio of total protein normalized to GAPDH (mean \pm SEM). ${ }^{*} p<0.05$.

adulthood. We demonstrate, using pharmacological (U0126) and gene-transfer approaches, that blockade of ERK2 activity can mimic the FLX-induced antidepressant-like behavioral profile, while enhancing ERK2 activity opposes the antidepressant-like behavioral profile.

Early-life exposure to FLX influenced responsivity to aversive situations $24 \mathrm{~h}$ after exposure to social defeat stress in adulthood. Adult mice pretreated with FLX during adolescence displayed decreased sensitivity to inescapable stress, as they did not exhibit the characteristic social avoidance induced by repeated episodes of social defeat (Berton et al., 2006), and by showing significantly higher latencies to immobility and decreased total immobility (i.e., antidepressant-like effect) in the forced swimming procedure (Porsolt et al., 1977). Paradoxically, these mice also displayed increased reactivity to anxiogenic stimuli-adult mice pretreated with FLX during adolescence spent significantly less time in the open arms of the EPM. Importantly, these enduring FLX-induced effects were not the result of changes in basal levels of social behavior (Fig. 1e) or general locomotor activity (Fig. 1g). These data are in agreement with recent reports demonstrating that FLX exposure during periods before adulthood result in decreased reactivity to forced swimming stress (Karpova et al., 2009; Iñiguez et al., 2010a), along with enhanced sensitivity to anxietyinducing situations in adulthood (Homberg et al., 2011). Decreased sensitivity to inescapable stress after adolescent FLX counters reports showing that prenatal and preadolescent (P4P21) FLX administration renders rodents more vulnerable to behavioral despair in adulthood (Ansorge et al., 2004; Lisboa et al.,
2007; Popa et al., 2008), thus indicating that exposure to FLX across specific windows of development leads to distinct functional outcomes in adulthood (Airan et al., 2007; Olivier et al., 2011).

The neurobiological mechanisms underlying these FLX-induced effects are unknown. In adults, antidepressants regulate expression of complex intracellular signaling molecules such as BDNF/ERK/ mTOR/CREB and their activity, factors associated with lasting synaptic changes influencing behavioral functioning (Duman and Monteggia, 2006; Krishnan and Nestler, 2008; Warren et al., 2011; Duman and Voleti, 2012). Several reports implicate ERK2, a key signaling molecule downstream of BDNF (Numakawa et al., 2010), in mediating the deleterious effects of stress (Einat et al., 2003; Gourley et al., 2008; Iñiguez et al., 2010b). Here we show that ERK2/CREB mRNA was decreased $24 \mathrm{~h}$ after chronic FLX exposure in the adolescent VTA. Unexpectedly, ERK2/ CREB mRNA expression remained downregulated into adulthood (Figs. $3 a-c, 6$ ). Because changes in gene expression do not necessarily translate into changes at the protein level and may not directly represent activity of these enzymes (Lee et al., 2003; Mehra et al., 2003), we assessed phosphorylation levels of key ERK-related proteins in adulthood. We found that exposure to FLX during adolescence decreased ERK2, RSK, CREB, and MTOR phosphorylation within the VTA, with no change in total levels of these proteins. These findings are consistent with studies demonstrating that FLX exposure blocks ERK phosphorylation in vivo (Fumagalli et al., 2005; Warren et al., 2011) and in vitro (Stepulak et al., 2008; Labasque et al., 2010), resulting in decreased ERK activity (Carlini et al., 2012). Our data, therefore, strongly indicate that the behavioral and therapeutic effects of FLX are mediated, at least in part, via decreases in ERK2 activity within the VTA. This is further supported by studies showing that decreased CREB expression, a downstream transcription factor of ERK (Carlezon et al., 2005), mediates antidepressant-like responses (Pliakas et al., 2001; Conti et al., 2002; Newton et al., 2002; Wallace et al., 2009), whereas increased CREB activity within the VTA-nucleus accumbens circuit increases sensitivity to the adverse effects of inescapable stress (Pliakas et al., 2001; Carlezon et al., 2005).

Because adolescent FLX treatment decreased reactivity to behavioral despair along with decreased ERK signaling within the VTA, it was of interest to determine whether blocking ERK would mimic, whereas increasing ERK activity would reverse, the enduring FLX-induced antidepressant-like behavioral profile. We took this approach because exposure to inescapable stress (i.e., social defeat) increases ERK2 mRNA (Fig. 3e) and ERK2 protein phosphorylation (Iñiguez et al., 2010b), while inhibiting ERK (U0126) within the VTA results in antidepressant-like responses (Fig. $4 c, d$ ). Using virus vectors, we found that increasing ERK2 activity within the VTA of adult mice, regardless of adolescent FLX treatment, renders them susceptible to a submaximal episode of defeat stress, conditions that are not sufficient to 
induce avoidance behaviors in control mice (Krishnan et al., 2007). Interestingly, FLX-pretreated mice receiving HSVwtERK2 spent significantly less time interacting with a social target, thus reversing the long-lasting antidepressant phenotype induced by adolescent FLX exposure (Fig. 1c,d). Importantly, this finding is reminiscent of the avoidance/depressive-like behavior exhibited by VEH-pretreated mice after exposure to $10 \mathrm{~d}$ of social defeat stress (Fig. 1c), or those receiving HSVwtERK2 and exposed to the TST (Fig. $5 f$ ). Together, these findings strongly implicate ERK activity as a modulator of responsiveness to stress during adolescence (Figs. 3b, left, 6b, left) and adulthood (Iñiguez et al., 2010b).

To better delineate whether the behavioral effects of ERK activity within the VTA are age specific, we examined whether viralmediated regulation of ERK2 activity would influence behavioral responses to aversive stimuli in drug-free adolescent rats (agematched to FLX treatment). We decided to use rats, given their larger anatomy, thus making it easier to target the adolescent VTA. Here, we demonstrate, for the first time, that downregulating ERK2 levels with HSV-dnERK2 in adolescence recapitulates the antidepressant-like phenotype observed in juvenile rats and mice after FLX exposure (Reed et al., 2008; Iñiguez et al., 2010a; Brookshire and Jones, 2012). In contrast, increasing ERK2 levels using HSV-wtERK2 induces depressive-like responses (Fig. 8e,f) similar to those observed after chronic stress. Together, these findings indicate that ERK2 expression within the adolescent VTA regulates responsiveness to behavioral despair measures in an oppositional manner: decreased ERK activity reduces sensitivity to stress, as seen after FLX treatment, while increasing ERK activity induces a behavioral phenotype commonly seen after exposure to chronic stress, data that are consistent with the role of ERK within the VTA of adult rodents (Iñiguez et al., 2010b). Interestingly, the ability of ERK to regulate responses to anxiety-inducing situations appears age specific. In adolescents, FLX treatment or downregulation of ERK2 activity within the VTA results in anxiogenic-like effects (Fig. 9), whereas in adults similar responses are seen only after chronic stress or viral-mediated increases in ERK2 activity (Iñiguez et al., 2010b). Adolescent rats microinjected with HSV-dnERK2 spent significantly more time in the closed arms of the EPM and produced more fecal boli, both measures of anxiety, while those receiving HSV-wtERK2 displayed the opposite behavioral profile. The reason for these
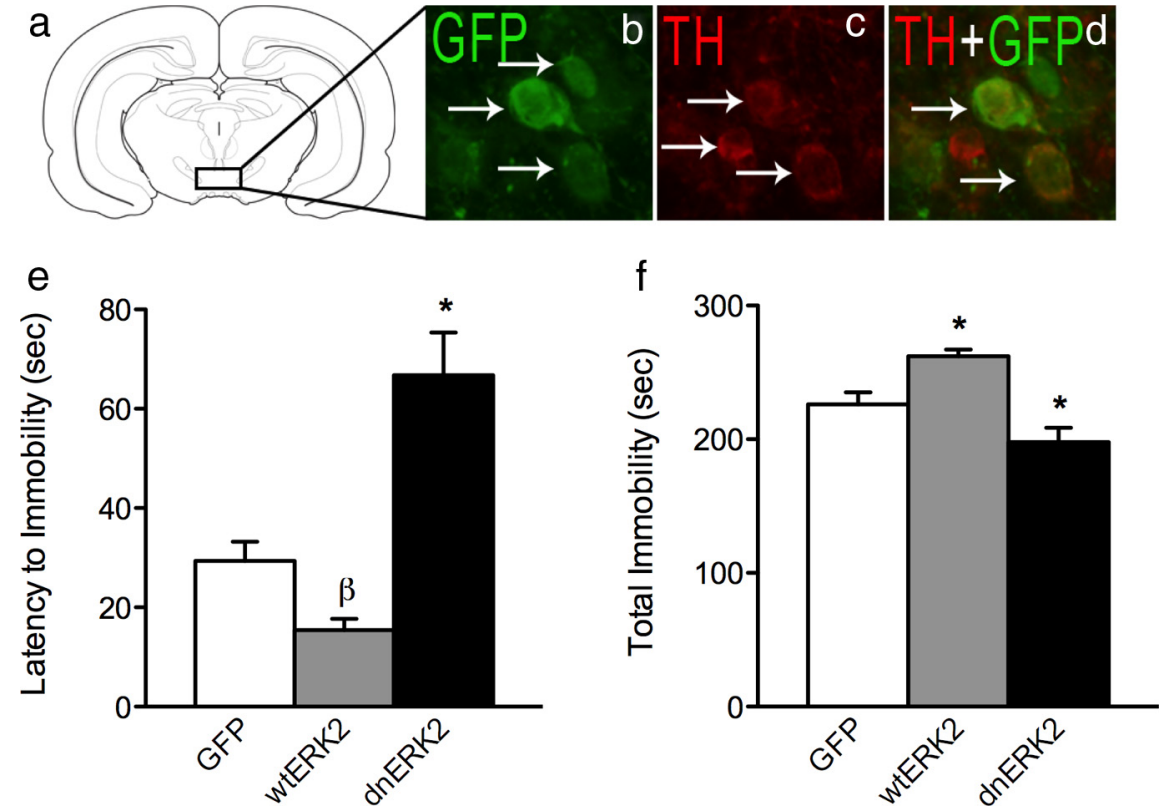

Figure 8. ERK2 within the VTA regulates behavioral responses to forced swimming stress in the adolescent rat. $\boldsymbol{a}$, Rostral region of the VTA to which microinjections of virus vectors were targeted ( $\sim 4.9 \mathrm{~mm}$ caudal from bregma; Paxinos and Watson, 1997). $\boldsymbol{b}$, Cells expressing wtERK2-GFP (green, cyanine 2) fluorescence. c, Cells expressing TH (red, cyanine 3) fluorescence. $\boldsymbol{d}$, Merged image of $\boldsymbol{b}$ and $\boldsymbol{c}$ showing dual-labeled neurons in the VTA (magnification, $400 \times$ ). Arrows indicate labeled cells. $\boldsymbol{e}$, Latencies to become immobile were decreased in adolescent rats receiving HSV-wtERK2 $(\beta p=0.05)$ and significantly increased in rats receiving HSV-dnERK2 $(p<0.05)$ when compared with the HSV-GFP controls $(n=9-10$ per group). $\boldsymbol{f}$, Total immobility was also influenced by virus treatment, with HSV-wtERK2-treated rats showing higher total immobility and the HSV-dnERK2-treated rats showing lower total immobility, when compared with the HSV-GFP controls. Data are presented as the mean \pm SEM. ${ }^{*} p<0.05$.
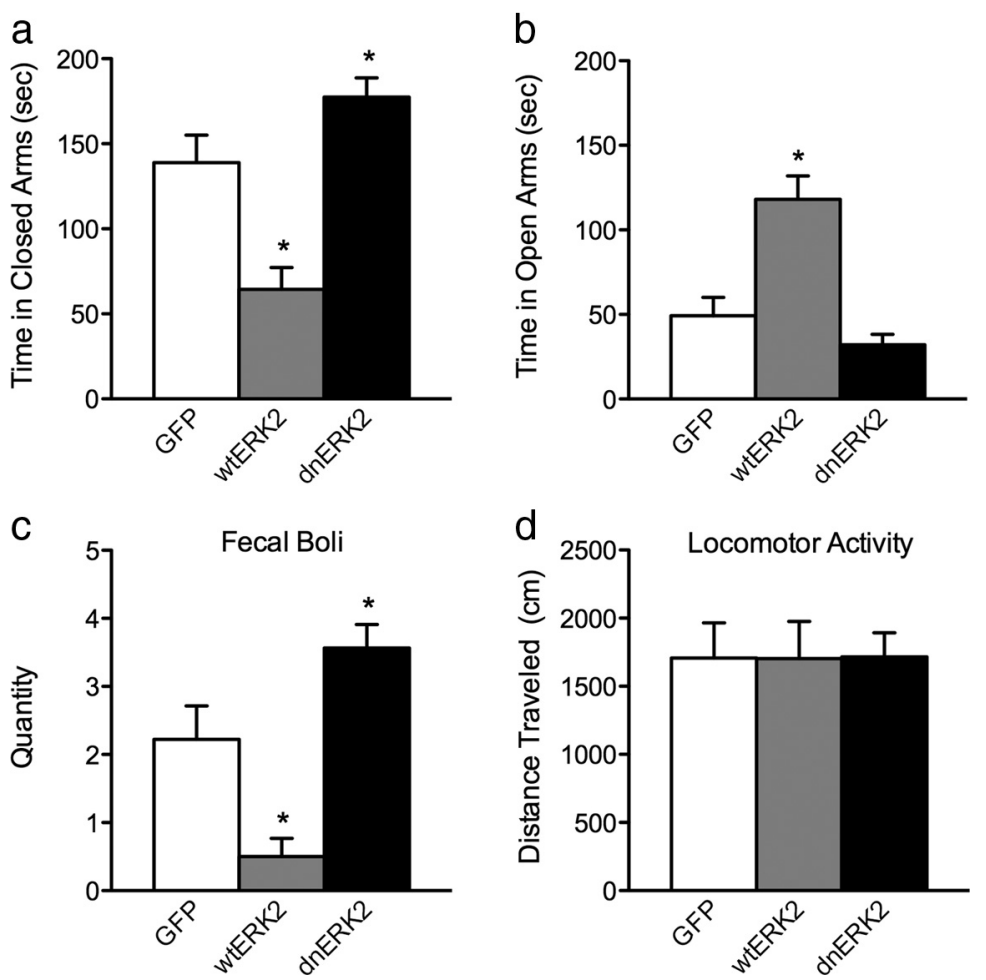

Figure 9. ERK2 within the VTA of adolescent rats regulates behavioral reactivity to the anxiety-eliciting environment of the elevated plus maze ( $n=8-9$ per group). $\boldsymbol{a}$, Rats overexpressing HSV-wtERK2 spent less time in the closed arms of the maze and those overexpressing HSV-dnERK2 spent more time in the closed arms of the maze when compared with the HSV-GFP-treated controls. $\boldsymbol{b}$, Rats receiving HSV-wtERK2 also spent more time in the open arms of the maze when compared with the HSV-GFP controls. c, The number of fecal boli (a measure of anxiety-like behavior) was also influenced by virus treatment, with rats receiving HSV-wtERK2 producing fewer fecal boli than those receiving HSV-dnERK2 compared with the HSV-GFP controls. $\boldsymbol{d}$, No differences in total locomotor activity were observed between the groups $(p>0.05)$. Data are presented as the mean \pm SEM. ${ }^{*} p<0.05$. 
age-dependent, paradoxical results is unknown - the distinction between anxiety and depression is not well understood, with no known biologically based differences (Berton and Nestler, 2006). It is conceivable that the same way that manipulations of ERK signaling in different brain regions (i.e., hippocampus vs VTA) bring about distinct behavioral phenotypes in response to stress (Shirayama et al., 2002; Berton et al., 2006; Duman and Monteggia, 2006; Krishnan et al., 2007), may also bring about opposite behavioral outputs within the same brain area as a function of age, such as increased sensitivity to stress accompanied by decreased anhedonia (Kalueff et al., 2006; Iñiguez et al., 2010b). Together, these findings underscore the complexity of drug and intracellular manipulations in the immature brain (Spear, 2000; Bolaños et al., 2003b, 2008; Warren et al., 2011), and detailed assessments of these phenomena across ages and different brain areas are needed. Furthermore, future investigations must examine the type of VTA neurons (i.e., dopaminergic vs GABAergic) that are primarily responsible for modulating the ERK2-mediated behavioral responses observed after FLX exposure, given that the pharmacological agent (U0126) and HSV vectors used in this investigation are not cell type specific.

Overall, our study shows that FLX administration during adolescence decreases sensitivity to behavioral despair, while enhancing responsivity to anxiety-inducing situations in adulthood. This complex behavioral profile is accompanied by a sustained decrease in ERK2 activity within the VTA that, in turn, is capable of modulating behavioral responsiveness to emotioneliciting environments in an age-specific manner. This study further points to a novel role for decreased ERK2 activity within the adolescent VTA in regulating the stress sequelae and the antidepressant effects of FLX. Within this context, these data may shed light into potential biomarkers underlying the etiology of mood dysregulation and antidepressant response during adolescence, which, in turn, may provide new modalities to more effectively treat mood-related disorders in juvenile populations.

\section{References}

Abreu-Villaça Y, Filgueiras CC, Guthierrez M, Medeiros AH, Mattos MA, Pereira Mdos S, Manhães AC, Kubrusly RC (2010) Exposure to tobacco smoke containing either high or low levels of nicotine during adolescence: differential effects on choline uptake in the cerebral cortex and hippocampus. Nicotine Tob Res 12:776-780. CrossRef Medline

Airan RD, Meltzer LA, Roy M, Gong Y, Chen H, Deisseroth K (2007) Highspeed imaging reveals neurophysiological links to behavior in an animal model of depression. Science 317:819-823. CrossRef Medline

Andersen SL (2003) Trajectories of brain development: point of vulnerability or window of opportunity? Neurosci Biobehav Rev 27:3-18. CrossRef Medline

Ansorge MS, Zhou M, Lira A, Hen R, Gingrich JA (2004) Early-life blockade of the 5-HT transporter alters emotional behavior in adult mice. Science 306:879-881. CrossRef Medline

Azmitia EC (2007) Serotonin and brain: evolution, neuroplasticity, and homeostasis. Int Rev Neurobiol 77:31-56. CrossRef Medline

Barrot M, Olivier JD, Perrotti LI, DiLeone RJ, Berton O, Eisch AJ, Impey S, Storm DR, Neve RL, Yin JC, Zachariou V, Nestler EJ (2002) CREB activity in the nucleus accumbens shell controls gating of behavioral responses to emotional stimuli. Proc Natl Acad Sci U S A 99:11435-11440. CrossRef Medline

Berton O, Nestler EJ (2006) New approaches to antidepressant drug discovery: beyond monoamines. Nat Rev Neurosci 7:137-151. CrossRef Medline

Berton O, McClung CA, Dileone RJ, Krishnan V, Renthal W, Russo SJ, Graham D, Tsankova NM, Bolanos CA, Rios M, Monteggia LM, Self DW, Nestler EJ (2006) Essential role of BDNF in the mesolimbic dopamine pathway in social defeat stress. Science 311:864-868. CrossRef Medline

Birmaher B (1998) Should we use antidepressant medications for children and adolescents with depressive disorders? Psychopharmacol Bull 34:3539. Medline
Birmaher B, Brent D, Bernet W, Bukstein O, Walter H, Benson RS, Chrisman A, Farchione T, Greenhill L, Hamilton J, Keable H, Kinlan J, Schoettle U, Stock S, Ptakowski KK, Medicus J (2007) Practice parameter for the assessment and treatment of children and adolescents with depressive disorders. J Am Acad Child Adolesc Psychiatry 46:1503-1526. CrossRef Medline

Blakemore SJ, Choudhury S (2006) Development of the adolescent brain: implications for executive function and social cognition. J Child Psychol Psychiatry 47:296-312. CrossRef Medline

Bolaños CA, Perrotti LI, Edwards S, Eisch AJ, Barrot M, Olson VG, Russell DS, Neve RL, Nestler EJ (2003a) Phospholipase Cgamma in distinct regions of the ventral tegmental area differentially modulates mood-related behaviors. J Neurosci 23:7569-7576. Medline

Bolaños CA, Barrot M, Berton O, Wallace-Black D, Nestler EJ (2003b) Methylphenidate treatment during pre- and periadolescence alters behavioral responses to emotional stimuli at adulthood. Biol Psychiatry 54:1317-1329. CrossRef Medline

Bolaños CA, Willey MD, Maffeo ML, Powers KD, Kinka DW, Grausam KB, Henderson RP (2008) Antidepressant treatment can normalize adult behavioral deficits induced by early-life exposure to methylphenidate. Biol Psychiatry 63:309-316. CrossRef Medline

Brookshire BR, Jones SR (2012) Chronic methylphenidate administration in mice produces depressive-like behaviors and altered responses to fluoxetine. Synapse 66:844-847. CrossRef Medline

Burke KC, Burke JD Jr, Regier DA, Rae DS (1990) Age at onset of selected mental disorders in five community populations. Arch Gen Psychiatry 47:511-518. CrossRef Medline

Cao JL, Covington HE 3rd, Friedman AK, Wilkinson MB, Walsh JJ, Cooper DC, Nestler EJ, Han MH (2010) Mesolimbic dopamine neurons in the brain reward circuit mediate susceptibility to social defeat and antidepressant action. J Neurosci 30:16453-16458. CrossRef Medline

Carlezon WA Jr, Thome J, Olson VG, Lane-Ladd SB, Brodkin ES, Hiroi N, Duman RS, Neve RL, Nestler EJ (1998) Regulation of cocaine reward by CREB. Science 282:2272-2275. CrossRef Medline

Carlezon WA Jr, Duman RS, Nestler EJ (2005) The many faces of CREB. Trends Neurosci 28:436-445. CrossRef Medline

Carlini VP, Poretti MB, Rask-Andersen M, Chavan RA, Ponzio MF, Sawant RS, de Barioglio SR, Schiöth HB, de Cuneo MF (2012) Differential effects of fluoxetine and venlafaxine on memory recognition: possible mechanisms of action. Prog Neuropsychopharmacol Biol Psychiatry 38: 159-167. CrossRef Medline

Chaudhury D, Walsh JJ, Friedman AK, Juarez B, Ku SM, Koo JW, Ferguson D, Tsai HC, Pomeranz L, Christoffel DJ, Nectow AR, Ekstrand M, Domingos A, Mazei-Robison MS, Mouzon E, Lobo MK, Neve RL, Friedman JM, Russo SJ, Deisseroth K, et al (2013) Rapid regulation of depressionrelated behaviours by control of midbrain dopamine neurons. Nature 493:532-536. Medline

Conti AC, Cryan JF, Dalvi A, Lucki I, Blendy JA (2002) cAMP response element-binding protein is essential for the upregulation of brain-derived neurotrophic factor transcription, but not the behavioral or endocrine responses to antidepressant drugs. J Neurosci 22:3262-3268. Medline

Correll CU, Kratochvil CJ, March JS (2011) Developments in pediatric psychopharmacology: focus on stimulants, antidepressants, and antipsychotics. J Clin Psychiatry 72:655-670. CrossRef Medline

Coyle JT, Pine DS, Charney DS, Lewis L, Nemeroff CB, Carlson GA, Joshi PT, Reiss D, Todd RD, Hellander M (2003) Depression and bipolar support alliance consensus statement on the unmet needs in diagnosis and treatment of mood disorders in children and adolescents. J Am Acad Child Adolesc Psychiatry 42:1494-1503. CrossRef Medline

de Kloet ER, Joëls M, Holsboer F (2005) Stress and the brain: from adaptation to disease. Nat Rev Neurosci 6:463-475. CrossRef Medline

Detke MJ, Lucki I (1996) Detection of serotonergic and noradrenergic antidepressants in the rat forced swimming test: the effects of water depth. Behav Brain Res 73:43-46. Medline

Duman RS, Monteggia LM (2006) A neurotrophic model for stress-related mood disorders. Biol Psychiatry 59:1116-1127. CrossRef Medline

Duman RS, Voleti B (2012) Signaling pathways underlying the pathophysiology and treatment of depression: novel mechanisms for rapid-acting agents. Trends Neurosci 35:47-56. CrossRef Medline

Einat H, Yuan P, Gould TD, Li J, Du J, Zhang L, Manji HK, Chen G (2003) The role of the extracellular signal-regulated kinase signaling pathway in mood modulation. J Neurosci 23:7311-7316. Medline 
Eisch AJ, Bolaños CA, de Wit J, Simonak RD, Pudiak CM, Barrot M, Verhaagen J, Nestler EJ (2003) Brain-derived neurotrophic factor in the ventral midbrain-nucleus accumbens pathway: a role in depression. Biol Psychiatry 54:994-1005. CrossRef Medline

Englander MT, Dulawa SC, Bhansali P, Schmauss C (2005) How stress and fluoxetine modulate serotonin $2 \mathrm{C}$ receptor pre-mRNA editing. J Neurosci 25:648-651. CrossRef Medline

Franklin K, Paxinos G (2008) The mouse brain in stereotaxic coordinates, compact Ed 3. New York: Elsevier.

Fumagalli F, Molteni R, Calabrese F, Frasca A, Racagni G, Riva MA (2005) Chronic fluoxetine administration inhibits extracellular signal-regulated kinase 1/2 phosphorylation in rat brain. J Neurochem 93:1551-1560. CrossRef Medline

Ghisleni G, Kazlauckas V, Both FL, Pagnussat N, Mioranzza S, Rocha JB, Souza DO, Porciúncula LO (2008) Diphenyl diselenide exerts anxiolytic-like effect in Wistar rats: putative roles of GABAA and 5HT receptors. Prog Neuropsychopharmacol Biol Psychiatry 32:1508-1515. CrossRef Medline

Golden SA, Covington HE 3rd, Berton O, Russo SJ (2011) A standardized protocol for repeated social defeat stress in mice. Nat Protoc 6:1183-1191. CrossRef Medline

Gourley SL, Wu FJ, Taylor JR (2008) Corticosterone regulates pERK1/2 map kinase in a chronic depression model. Ann N Y Acad Sci 1148:509514. CrossRef Medline

Halladay LR, Iñiguez SD, Furqan F, Previte MC, Chisum AM, Crawford CA (2009) Methylphenidate potentiates morphine-induced antinociception, hyperthermia, and locomotor activity in young adult rats. Pharmacol Biochem Behav 92:190-196. CrossRef Medline

Hammerness PG, Vivas FM, Geller DA (2006) Selective serotonin reuptake inhibitors in pediatric psychopharmacology: a review of the evidence. J Pediatr 148:158-165. CrossRef Medline

Homberg JR, Olivier JD, Blom T, Arentsen T, van Brunschot C, Schipper P, Korte-Bouws G, van Luijtelaar G, Reneman L (2011) Fluoxetine exerts age-dependent effects on behavior and amygdala neuroplasticity in the rat. PLoS One 6:e16646. CrossRef Medline

Huang TY, Lin CH (2006) Role of amygdala MAPK activation on immobility behavior of forced swim rats. Behav Brain Res 173:104-111. CrossRef Medline

Iñiguez SD, Cortez AM, Crawford CA, McDougall SA (2008a) Effects of aripiprazole and terguride on dopamine synthesis in the dorsal striatum and medial prefrontal cortex of preweanling rats. J Neural Transm 115: 97-106. CrossRef Medline

Iñiguez SD, Warren BL, Neve RL, Nestler EJ, Russo SJ, Bolaños-Guzmán CA (2008b) Insulin receptor substrate-2 in the ventral tegmental area regulates behavioral responses to cocaine. Behav Neurosci 122:1172-1177. CrossRef Medline

Iñiguez SD, Warren BL, Parise EM, Alcantara LF, Schuh B, Maffeo ML, Manojlovic Z, Bolaños-Guzmán CA (2009) Nicotine exposure during adolescence induces a depression-like state in adulthood. Neuropsychopharmacology 34:1609-1624. CrossRef Medline

Iñiguez SD, Warren BL, Bolaños-Guzmán CA (2010a) Short- and longterm functional consequences of fluoxetine exposure during adolescence in male rats. Biol Psychiatry 67:1057-1066. CrossRef Medline

Iñiguez SD, Vialou V, Warren BL, Cao JL, Alcantara LF, Davis LC, Manojlovic Z, Neve RL, Russo SJ, Han MH, Nestler EJ, Bolaños-Guzmán CA (2010b) Extracellular signal-regulated kinase-2 within the ventral tegmental area regulates responses to stress. J Neurosci 30:7652-7663. CrossRef Medline

Iñiguez SD, Warren BL, Neve RL, Russo SJ, Nestler EJ, Bolaños-Guzmán CA (2010c) Viral-mediated expression of extracellular signal-regulated kinase-2 in the ventral tegmental area modulates behavioral responses to cocaine. Behav Brain Res 214:460 - 464. CrossRef MedlineDecember

Iñiguez SD, Charntikov S, Baella SA, Herbert MS, Bolaños-Guzmán CA, Crawford CA (2012) Post-training cocaine exposure facilitates spaital memory consolidation in c57bl/6 mice. Hippocampus 22:802-813. CrossRef Medline

Kalueff AV, Gallagher PS, Murphy DL (2006) Are serotonin transporter knockout mice "depressed"?: hypoactivity but no anhedonia. Neuroreport 17:1347-1351. CrossRef Medline

Kapornai K, Vetró A (2008) Depression in children. Curr Opin Psychiatry 21:1-7. CrossRef Medline

Karpova NN, Lindholm J, Pruunsild P, Timmusk T, Castrén E (2009) Longlasting behavioural and molecular alterations induced by early postnatal fluoxetine exposure are restored by chronic fluoxetine treatment in adult mice. Eur Neuropsychopharmacol 19:97-108. CrossRef Medline

Krishnan V, Nestler EJ (2008) The molecular neurobiology of depression. Nature 455:894-902. CrossRef Medline

Krishnan V, Han MH, Graham DL, Berton O, Renthal W, Russo SJ, Laplant Q, Graham A, Lutter M, Lagace DC, Ghose S, Reister R, Tannous P, Green TA, Neve RL, Chakravarty S, Kumar A, Eisch AJ, Self DW, Lee FS, et al (2007) Molecular adaptations underlying susceptibility and resistance to social defeat in brain reward regions. Cell 131:391-404. CrossRef Medline

Krishnan V, Han MH, Mazei-Robison M, Iñiguez SD, Ables JL, Vialou V, Berton O, Ghose S, Covington HE 3rd, Wiley MD, Henderson RP, Neve RL, Eisch AJ, Tamminga CA, Russo SJ, Bolaños CA, Nestler EJ (2008) AKT signaling within the ventral tegmental area regulates cellular and behavioral responses to stressful stimuli. Biol Psychiatry 64:691-700. CrossRef Medline

Labasque M, Meffre J, Carrat G, Becamel C, Bockaert J, Marin P (2010) Constitutive activity of serotonin $2 \mathrm{C}$ receptors at $\mathrm{G}$ protein-independent signaling: modulation by RNA editing and antidepressants. Mol Pharmacol 78:818-826. CrossRef Medline

LaPlant Q, Vialou V, Covington HE 3rd, Dumitriu D, Feng J, Warren BL, Maze I, Dietz DM, Watts EL, Iñiguez SD, Koo JW, Mouzon E, Renthal W, Hollis F, Wang H, Noonan MA, Ren Y, Eisch AJ, Bolaños CA, Kabbaj M, et al. (2010) Dnmt3a regulates emotional behavior and spine plasticity in the nucleus accumbens. Nat Neurosci 13:1137-1143. CrossRef Medline

Lee PS, Shaw LB, Choe LH, Mehra A, Hatzimanikatis V, Lee KH (2003) Insights into the relation between mrna and protein expression patterns: II. Experimental observations in Escherichia coli. Biotechnol Bioeng 84: 834-841. CrossRef Medline

Lisboa SF, Oliveira PE, Costa LC, Venâncio EJ, Moreira EG (2007) Behavioral evaluation of male and female mice pups exposed to fluoxetine during pregnancy and lactation. Pharmacology 80:49-56. CrossRef Medline

Mazzucchelli C, Brambilla R (2000) Ras-related and MAPK signalling in neuronal plasticity and memory formation. Cell Mol Life Sci 57:604-611. CrossRef Medline

Mehra A, Lee KH, Hatzimanikatis V (2003) Insights into the relation between mRNA and protein expression patterns: I. Theoretical considerations. Biotechnology and bioengineering 84:822-833. CrossRef Medline

Montgomery KC (1955) The relation between fear induced by novel stimulation and exploratory behavior. J Comp Physiol Psychol 48:254-260. CrossRef Medline

Nestler EJ, Carlezon WA Jr (2006) The mesolimbic dopamine reward circuit in depression. Biol Psychiatry 59:1151-1159. CrossRef Medline

Neve RL, Howe JR, Hong S, Kalb RG (1997) Introduction of the glutamate receptor subunit 1 into motor neurons in vitro and in vivo using a recombinant herpes simplex virus. Neuroscience 79:435-447. CrossRef Medline

Neville KA, Becker ML, Goldman JL, Kearns GL (2011) Developmental pharmacogenomics. Paediatr Anaesth 21:255-265. CrossRef Medline

Newton SS, Thome J, Wallace TL, Shirayama Y, Schlesinger L, Sakai N, Chen J, Neve R, Nestler EJ, Duman RS (2002) Inhibition of cAMP response element-binding protein or dynorphin in the nucleus accumbens produces an antidepressant-like effect. J Neurosci 22:10883-10890. Medline

Numakawa T, Suzuki S, Kumamaru E, Adachi N, Richards M, Kunugi H (2010) BDNF function and intracellular signaling in neurons. Histol Histopathol 25:237-258. Medline

Oberlander TF, Gingrich JA, Ansorge MS (2009) Sustained neurobehavioral effects of exposure to SSRI antidepressants during development: molecular to clinical evidence. Clin Pharmacol Ther 86:672-677. CrossRef Medline

Olivier JD, Blom T, Arentsen T, Homberg JR (2011) The age-dependent effects of selective serotonin reuptake inhibitors in humans and rodents: a review. Prog Neuropsychopharmacol Biol Psychiatry 35:1400-1408. CrossRef Medline

Parise EM, Alcantara LF, Warren BL, Wright KN, Hadad R, Sial OK, Kroeck KG, Iñiguez SD, Bolaños-Guzmán CA (2013) Repeated ketamine exposure induces an enduring resilient phenotype in adolescent and adult rats. Biol Psychiatry 74:750-759. CrossRef Medline

Paus T, Keshavan M, Giedd JN (2008) Why do many psychiatric disorders emerge during adolescence? Nat Rev Neurosci 9:947-957. CrossRef Medline 
Paxinos G, Watson C (1997) The rat brain in stereotaxic coordinates, Ed 3. San Diego: Academic.

Pliakas AM, Carlson RR, Neve RL, Konradi C, Nestler EJ, Carlezon WA Jr (2001) Altered responsiveness to cocaine and increased immobility in the forced swim test associated with elevated cAMP response elementbinding protein expression in nucleus accumbens. J Neurosci 21:73977403. Medline

Popa D, Léna C, Alexandre C, Adrien J (2008) Lasting syndrome of depression produced by reduction in serotonin uptake during postnatal development: evidence from sleep, stress, and behavior. J Neurosci 28:3546-3554. CrossRef Medline

Porsolt RD, Le Pichon M, Jalfre M (1977) Depression: a new animal model sensitive to antidepressant treatments. Nature 266:730-732. CrossRef Medline

Racagni G, Popoli M (2008) Cellular and molecular mechanisms in the long-term action of antidepressants. Dialogues Clin Neurosci 10:385400. Medline

Reed AL, Happe HK, Petty F, Bylund DB (2008) Juvenile rats in the forcedswim test model the human response to antidepressant treatment for pediatric depression. Psychopharmacology (Berl) 197:433-441. CrossRef Medline

Robinson MJ, Harkins PC, Zhang J, Baer R, Haycock JW, Cobb MH, Goldsmith EJ (1996) Mutation of position 52 in ERK2 creates a nonproductive binding mode for adenosine $5^{\prime}$-triphosphate. Biochemistry 35:5641-5646. CrossRef Medline

Safer DJ (2006) Should selective serotonin reuptake inhibitors be prescribed for children with major depressive and anxiety disorders? Pediatrics 118 : 1248-1251. CrossRef Medline

Shirayama Y, Chen AC, Nakagawa S, Russell DS, Duman RS (2002) Brainderived neurotrophic factor produces antidepressant effects in behavioral models of depression. J Neurosci 22:3251-3261. Medline

Spear LP (2000) The adolescent brain and age-related behavioral manifestations. Neurosci Biobehav Rev 24:417-463. CrossRef Medline

Stepulak A, Rzeski W, Sifringer M, Brocke K, Gratopp A, Kupisz K, Turski L,
Ikonomidou C (2008) Fluoxetine inhibits the extracellular signal regulated kinase pathway and suppresses growth of cancer cells. Cancer Biol Ther 7:1685-1693. CrossRef Medline

Steru L, Chermat R, Thierry B, Simon P (1985) The tail suspension test: a new method for screening antidepressants in mice. Psychopharmacology (Berl) 85:367-370. CrossRef Medline

Surget A, Tanti A, Leonardo ED, Laugeray A, Rainer Q, Touma C, Palme R, Griebel G, Ibarguen-Vargas Y, Hen R, Belzung C (2011) Antidepressants recruit new neurons to improve stress response regulation. Mol Psychiatry 16:1177-1188. CrossRef Medline

Vialou V, Robison AJ, Laplant QC, Covington HE 3rd, Dietz DM, Ohnishi YN, Mouzon E, Rush AJ 3rd, Watts EL, Wallace DL, Iñiguez SD, Ohnishi YH, Steiner MA, Warren BL, Krishnan V, Bolaños CA, Neve RL, Ghose S, Berton O, Tamminga CA, et al. (2010) DeltaFosB in brain reward circuits mediates resilience to stress and antidepressant responses. Nat Neurosci 13:745-752. CrossRef Medline

Wallace DL, Han MH, Graham DL, Green TA, Vialou V, Iñiguez SD, Cao JL, Kirk A, Chakravarty S, Kumar A, Krishnan V, Neve RL, Cooper DC, Bolaños CA, Barrot M, McClung CA, Nestler EJ (2009) CREB regulation of nucleus accumbens excitability mediates social isolation-induced behavioral deficits. Nat Neurosci 12:200-209. CrossRef Medline

Warren BL, Iñiguez SD, Alcantara LF, Wright KN, Parise EM, Weakley SK, Bolaños-Guzmán CA (2011) Juvenile administration of concomitant methylphenidate and fluoxetine alters behavioral reactivity to rewardand mood-related stimuli and disrupts ventral tegmental area gene expression in adulthood. J Neurosci 31:10347-10358. CrossRef Medline

Warren BL, Vialou VF, Iñiguez SD, Alcantara LF, Wright KN, Feng J, Kennedy PJ, Laplant Q, Shen L, Nestler EJ, Bolaños-Guzmán CA (2013) Neurobiological sequelae of witnessing stressful events in adult mice. Biol Psychiatry 73:7-14. CrossRef Medline

Zito JM, Tobi H, de Jong-van den Berg LT, Fegert JM, Safer DJ, Janhsen K, Hansen DG, Gardner JF, Glaeske G (2006) Antidepressant prevalence for youths: a multi-national comparison. Pharmacoepidemiol Drug Saf 15:793-798. CrossRef Medline 